Marquette University

e-Publications@Marquette

Psychology Faculty Research and Publications

Psychology, Department of

$1-1-2015$

\title{
Individual Differences in the Experience of Cognitive Workload
}

Stephen J. Guastello

Marquette University, stephen.guastello@marquette.edu

Anton Shircel

Marquette University

Matthew Malon

Marquette University

Paul Timm

Marquette University

Accepted version. Theoretical Issues in Ergonomics Science, Vol. 16, No. 1 (2015): 20-52. DOI. (C) 2015 Informa UK Limited. Used with permission. 


\title{
Individual Differences in the Experience of Cognitive Workload
}

\author{
Stephen J. Guastello \\ Department of Psychology, Marquette University, Milwaukee, WI \\ Anton Shircel \\ Department of Psychology, Marquette University, Milwaukee, WI \\ Matthew Malon \\ Department of Psychology, Marquette University, Milwaukee, WI \\ Paul Timm \\ Department of Psychology, Marquette University, Milwaukee, WI
}

\begin{abstract}
This study investigated the roles of four psychosocial variables - anxiety, conscientiousness, emotional intelligence, and Protestant work ethic - on subjective ratings of cognitive workload as measured by the Task Load Index (TLX) and the further connections between the four variables and TLX ratings of task performance. The four variables represented aspects of an underlying construct of elasticity versus rigidity in response to workload. Participants were 141 undergraduates who performed a vigilance task under different speeded conditions while working on a jigsaw puzzle for 90 minutes. Regression analysis showed that anxiety and emotional intelligence were the two variables most proximally related to TLX ratings. TLX ratings contributed to the prediction of performance on the puzzle, but not the vigilance task. Severity error bias was evident in some of the ratings. Although working in pairs improved performance, it also resulted in higher ratings of temporal demand and perceived performance pressure.
\end{abstract}

Keywords: cognitive workload, NASA task load index (TLX), conscientiousness, anxiety, dual task, emotional intelligence, group dynamics

Theoretical Issues in Ergonomics Science, Vol. 16, No. 1 (2015): pg. 20-52. DOI. This article is (C) Taylor \& Francis and permission has been granted for this version to appear in e-Publications@Marquette. Taylor \& Francis does not grant permission for this article to be further copied/distributed or hosted elsewhere without the express permission from Taylor \& Francis. 


\section{Introduction}

Several authors have made a cogent case for studying individual differences in personality, motivation, cognitive abilities, and coping strategies in the study of ergonomics problems (Baldwin 2009; Cox-Fuenzalida, Swickert, and Hittner 2004; Cox-Fuenzalida et al. 2006; Drury et al. 2009; Eysenck 2010; Guastello, Guastello, and Guastello 2013; Hancock, Hancock, and Warm 2009; Karwowski 2000; Matthews and Campbell 2009; Szalma 2008; Szalma and Taylor 2011; Szymura 2010; Verhagen 1993). In principle, such knowledge could be used to modify system designs so that individual differences no longer present meaningful variation in performance, to customise designs, and to take advantage of human capabilities and limitations. The present study is concerned with individual differences in the experience of cognitive workload as measured by the National Aeronautics and Space Administration (NASA) Task Load Index (TLX).

The second objective of the study was to examine and compare the relationships between the individual differences with TLX ratings and the individual differences with actual performance measures. TLX ratings have developed some good currency in workload studies because they capture psychological responses to workload manipulations that are not evident in the actual behaviours. People exert effort to maintain their performance levels in spite of changing environmental demands. It is only when the environmental demands exceed their abilities to cope that decrements in performance are observed (Hancock and Warm 1989). Thus the subjective experience of workload precedes the performance outcomes. There is no reason to assume, however, that individual differences that influence subjective ratings are always the same as those that correlate directly with performance. Thus the three-way relationships among individual differences, subjective ratings, and actual performance require systematic investigation.

Four particular variables were examined in this study in conjunction with research on cognitive workload. Two of them, anxiety and conscientiousness, originate from personality trait theories. The other two variables, work ethic and emotional intelligence (EI), are psychosocial constructs from other origins. The experimental setting studied here involved a dual-task assignment, one of which was a vigilance task and the other was assembling a jigsaw puzzle. Performance measures for both tasks were used in conjunction with the TLX and other research variables. The experiment also had two experimental manipulations with two conditions each: one was working alone or working in pairs; it was expected that the presence of other people could affect perceived workload. The other was a manipulation of work speed on the vigilance task such that some participants worked at

Theoretical Issues in Ergonomics Science, Vol. 16, No. 1 (2015): pg. 20-52. DOI. This article is (C) Taylor \& Francis and permission has been granted for this version to appear in e-Publications@Marquette. Taylor \& Francis does not grant permission for this article to be further copied/distributed or hosted elsewhere without the express permission from Taylor \& Francis. 
increasing speeds and the others worked at decreasing speeds. The following sections of this paper elaborate some theoretical issues in cognitive workload and fatigue, the TLX form of measurement, the personality and psychosocial variables, and social facilitation.

\subsection{Cognitive workload and fatigue}

Cognitive workload can be defined as '[the] level of attentional resources required to meet both objective and subjective criteria, which may be mediated by task demands, external support, and past experience' (Young and Stanton 2006). Both underload and overload can tax the individual's adaptive capacities and affect performance when the capacity limits are exceeded in either direction (Hancock and Warm 1989). Load capacity is now thought to be moderately flexible (Ralph, Gray, and Schoelles $\underline{2010}$ ), but it is likely to become more taxed when two or more tasks demand the same mental resources (Wickens 2002).

Fatigue is the loss of work capacity over time (Starch and Ash 1917); the same basic definition applies to physical and mental fatigue. In the case of cognitive fatigue, it has been challenging to separate workload and fatigue effects (Ackerman 2011; Guastello, Boeh, Schimmels et al. 2012; Guastello, Boeh, Shumaker et al. 2012; Guastello, Boeh et al. 2013; Hancock and Desmond 2001; Matthews et al. 2012). Evidence suggests that cognitive fatigue results from prolonged and significant demands on the executive function within working memory (Logie 2011), and is a more likely result of work time on a specific mental task, rather that total work time on a group of mental tasks done in series (Guastello, Boeh, Schimmels et al. 2012). Switching tasks can alleviate fatigue, although the act of switching tasks can place additional demands on working memory, particularly if it involves switching to a more demanding task from a boring one (Alves and Kelsey 2010; Guastello, Gorin et al. 2012). Time has two effects on workload and fatigue: although work capacity drops over time and thus reduces observable performance (fatigue), practice, adaptive responses, and automaticity are working in the other direction over time to improve performance in some way or lessen the demands of production. The regrouping strategies could also be applied to the management of cognitive workload.

The response to the nexus of phenomena surrounding cognitive workload and fatigue was to develop two non-linear dynamical (cusp catastrophe) models, one for workload and one for fatigue, and an experimental design that tests both models in a given situation (Guastello, Boeh, Schimmels et al. 2012; Guastello, Boeh, Shumaker et al. 2012; Guastello, Boeh et al. 2013; Guastello, Malon et al. 2013; Guastello, Shircel et al. 2013). There are places where individual differences play an important role within each of the two

Theoretical Issues in Ergonomics Science, Vol. 16, No. 1 (2015): pg. 20-52. DOI. This article is (c) Taylor \& Francis and permission has been granted for this version to appear in e-Publications@Marquette. Taylor \& Francis does not grant permission for this article to be further copied/distributed or hosted elsewhere without the express permission from Taylor \& Francis. 
models. In the case of workload, individual differences contribute to elasticity or resilience, which are features of adaptability to changing levels of workload (Guastello 1985) or other forms of stress (Pincus and Metten 2010). In the case of fatigue, compensatory mental abilities can support, or dissipate the demand on, the primary resource that fatigues and results in a performance decline. The notion of compensatory mental abilities is consistent with what is currently known about working memory capacity being derived from several intellectual resources and pulled together by the executive function (Kane and Engle 2002; Logie 2011). Both non-linear models have built-in provisions for situational elements that promote improvement and decline of performance with adjustments in workload and elements that mitigate fatigue.

The cusp catastrophe models for cognitive workload and fatigue appear in Figure 1. The cusp response surface is three-dimensional and describes two stable states of behaviour. Change between the two states is a function of two control parameters, asymmetry ( $a$ ) and bifurcation ( $b$ ). At low values of $b$, change is smooth; $y$ is a continuous monotonic function of $a$. At high values of $b$, the relationship between $a$ and $y$ is discontinuous depending on the values of $a$. At the lower end of the a scale, $y$ is unresponsive to changes in $a$. Something similar occurs at the upper end of the a scale. In the middle of the a scale, however, $y$ changes suddenly (i.e. catastrophically) as a function of $a$.

Figure 1. Cusp catastrophe models for cognitive workload (upper) and fatigue (lower).

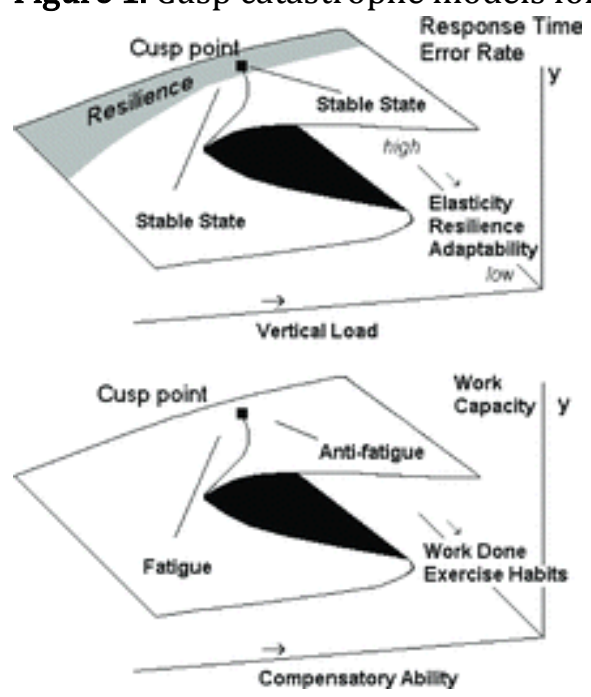

At middle values of $a$, changes occur around the upper modes and lower modes; changes are large between the modes and relatively small within the modes. There are two thresholds for behaviour change, one ascending and one descending. The phenomenon of

Theoretical Issues in Ergonomics Science, Vol. 16, No. 1 (2015): pg. 20-52. DOI. This article is (C) Taylor \& Francis and permission has been granted for this version to appear in e-Publications@Marquette. Taylor \& Francis does not grant permission for this article to be further copied/distributed or hosted elsewhere without the express permission from Taylor \& Francis. 
hysteresis simultaneously refers to relatively frequent changes between two behavioural states and the two different thresholds for change. The equation for the cusp response surface can be rendered statistically and tested literally.

Elasticity and its opposite, rigidity, as used here are analogous to a similar construct in material science. The amount of vertical weight is the asymmetry (a) parameter. A rigid material will snap if it is stressed too extensively. A more elastic material would show some signs of bending under increased load, but would revert to its undamaged form or show less deformity due to stress (Gordon 1978; Guastello 1985; Zeeman 1977). The cognitive analogy here is that psychological characteristics of rigidity can go a long way toward minimising the effect of workload or increasing workload, but with the result of a sudden burst of errors when load exceeds a certain level. More elastic characteristics are likely to buffer increased load and minimise performance deficits. Elasticity constructs might be recognised as 'coping' or 'adaptability'; the important feature is that the individual makes some internal adjustment that could involve reorganising the execution of the task or responding differently to cues produced from the task experience. The relationship between workload demand, coping, and performance forms the crux of the dynamic adaptability model advanced by Hancock and Warm (1989).

Depletion of work capacity caused by fatigue is typically observed as a work curve that plots performance over time. There is a sharp drop in performance when fatigue sets in, which is pronounced in vigilance tasks (Hancock 2013). The performance decrement is coupled with an increase in variability over time (Starch and Ash 1917; Guastello and McGee 1987). However, not everyone experiences a decline as a result of the same expenditures. Some show an increase in physical strength akin to 'just getting warmed up,' while others show stably high or lower performance levels for the duration of the work period. The total quantity of work done would be the main contributor to the bifurcation parameter: If the individual did not accomplish much in a fixed amount of time, there would be comparably little drain on work capacity. The asymmetry parameter in the fatigue model would consist of compensatory abilities that assist with the demands placed on a particular mental resource that is imposed by the task.

Ideally the results supporting a cusp model should show an equal or greater degree of fit between the data and the model compared to the next best theoretical model, which was a linear function in the cases of cognitive workload and fatigue tested thus far. The results should also identify bifurcation and asymmetry variables for the cusps. Because the models were tested in pairs, it was possible to observe a strong workload effect but a weaker fatigue effect or vice versa.

Theoretical Issues in Ergonomics Science, Vol. 16, No. 1 (2015): pg. 20-52. DOI. This article is (C) Taylor \& Francis and permission has been granted for this version to appear in e-Publications@Marquette. Taylor \& Francis does not grant permission for this article to be further copied/distributed or hosted elsewhere without the express permission from Taylor \& Francis. 
Five experiments on the pair of cusp of models have been completed to date. The first experiment of the series $(N=181)$ evaluated cognitive workload and fatigue in an episodic memory task (Guastello, Boeh, Shumaker et al. 2012). The second experiment ( $N$ $=130$ ), which focused on a pictorial memory task (Guastello, Boeh et al. 2012) required the participants to work alone first and then in competition with another participant under different conditions for time pressure and incentives; the participants also completed a brief version of the episodic memory task before and after an hour of work on the main task. The third experiment $(N=105)$ investigated cognitive workload and fatigue outcomes for multitasking compared to single tasks in addition to assessing the impact of voluntary and involuntary task ordering (Guastello, Boeh et al. 2013). The fourth experiment $(N=141)$ involved a vigilance dual task in which the participants watched a virtual reality security camera and signalled the presence of an intruder while completing a jigsaw puzzle; the participants worked either alone or in pairs (Guastello, Malon et al. 2013). The fifth experiment involved optimisation and risk taking in a financial decisionmaking task (Guastello, Shircel et al. 2013).

There were several important findings from the experiments thus far: (1) the cusp models (unweighted average $R^{2}=.46$ ) were more accurate than the best linear alternatives (unweighted average $R^{2}=.29$ ) for predicting change in performance as a function of workload or fatigue. (2) The manipulation of vertical load, which included incentives for competition, worked as expected as asymmetry variables in the workload models. (3) Elasticity versus rigidity variables variously included anxiety, frustration, selfdetermined task order versus experiment-driven task order, conscientiousness and selfcontrol, field dependence, and work ethic. (4) In the fatigue models, the measurement of work done between the starting and ending observations worked as a bifurcation variable as expected. (5) Compensatory abilities in the fatigue model included arithmetic ability relative to the episodic memory task, peak memory span relative to the pictorial memory task, spelling ability relative to the perceptual-motor tasks, and field dependence relative to the financial decision-making task.

One aspect of the research agenda for the further development of the two non-linear dynamical models involves the search for variables that would correspond to elasticity (resilience) or compensatory abilities, and to identify any situational influences that might affect the relevance of those variables. The present study was motivated by the search for elasticity constructs pertinent to workload and the further assessment of the relationships between some candidate variables with the popular, but static, TLX measurements of subjective workload. Four candidate constructs are described in further detail below.

Theoretical Issues in Ergonomics Science, Vol. 16, No. 1 (2015): pg. 20-52. DOI. This article is (C) Taylor \& Francis and permission has been granted for this version to appear in e-Publications@Marquette. Taylor \& Francis does not grant permission for this article to be further copied/distributed or hosted elsewhere without the express permission from Taylor \& Francis. 
NOT THE PUBLISHED VERSION; this is the author's final, peer-reviewed manuscript. The published version may be accessed by following the link in the citation at the bottom of the page.

\subsection{NASA Task Load Index}

The TLX is a subjective measure of workload in six domains that represent costs to the operators who are performing a task: mental demand, physical demand, temporal demand, performance demand, effort required to meet the performance demand, and experience of frustration (Hart 1986; Hart and Staveland 1988). The first three domains are properties of the task and the latter three capture the person's response to the task. The original method of compiling TLX results was a labour-intensive process. Operators had to pick which of two of dimensions contributed more to the task; these paired comparisons were made for all possible pairs of the six dimensions. In addition, participants rated each domain on a scale ranging from 0 to 100 . A workload scale would then be compiled from the ratings and the weights obtained from the paired comparison technique (Byers et al. 1988).

One proposed method for simplifying the scoring procedure eliminated the paired comparisons procedure and only used the sum of the six scales on the original 0-100 scale. This version was known as the Raw Task Load Index (RTLX). Not surprisingly, studies (Byers, Bittner, and Hill 1989; Dickinson, Byblow, and Ryan 1993; Noyes and Bruneau 2007) showed that the TLX and RTLX measures of workload produced essentially the same results, with correlations above .95. Braarud (2001) later reduced the 0-100 scale to a 010 scale, which is consistent with the standard advice for rating scales that a scale with 511 markers is generally sufficient for capturing psychologically meaningful differences in observation (Leary 2012). The three versions of the TLX scale continue to be employed in contemporary research (Dey and Mann 2010); the simpler acronym TLX is adopted throughout this paper with the understanding that some researchers' procedures could vary as just described.

The majority of research with the TLX was conducted using a conventional paperand-pencil format. Some researchers, however, experimented with a computer-based version of TLX. Ideally the two media should produce the same measurements, but unfortunately, completing the rating scales on a computer produced a higher workload than the paper-and-pencil format (Noyes and Bruneau 2007). Practically, this result means the computer medium increases the overall workload the participant subjectively experienced. It is thus recommended that further research with the TLX should stick with the traditional method of assessment, which can be completed at a lower cost to the participants and is thus less intrusive.

Theoretical Issues in Ergonomics Science, Vol. 16, No. 1 (2015): pg. 20-52. DOI. This article is (c) Taylor \& Francis and permission has been granted for this version to appear in e-Publications@Marquette. Taylor \& Francis does not grant permission for this article to be further copied/distributed or hosted elsewhere without the express permission from Taylor \& Francis. 
Another methodological issue is the extent to which TLX scores are influenced by context in which task evaluation is made (Moroney, Biers, and Eggemeier 1995). Taking the TLX while still in the cockpit may produce different workload results than taking the test in a classroom safely on the ground (Moroney, Biers, and Eggemeier 1995). Similar to the context question is the question of order effects for two different tasks or versions of tasks. For example, suppose Group A experienced harder levels of the same task followed by easier levels later on. Group B, meanwhile, was exposed to easier levels of the task first and then finished with the harder level. How would these two groups rate the task overall on the six dimensions? The earlier research indicated that the TLX was not vulnerable to order effects (Dickinson, Byblow, and Ryan 1993). The present study did provide a new opportunity to study order effects on the TLX.

The differences in the TLX scoring methods do not undermine a more important observation that the measure is sensitive to workload differences as observed in many contexts (Wierwille and Eggemeier 1993), including both real (Shively et al. 1987) and simulated flight tasks (Battiste and Bortolussi 1988; Nataupsky and Abbott 1987; Tsang and Johnson 1989; Vidulich and Bortolussi 1988) and with remote-controlled vehicles (Byers et al. 1988; Wierwille and Eggemeier 1993). Sensitivity to workload differences has also been demonstrated with vigilance tasks (Hart 2008; Warm, Dember, and Hancock 1996). Although vigilance tasks seem simple and undemanding at first glance, they produce high workload scores on the TLX (Temple et al. 2000; Warm, Parasuraman, and Matthews 2008). The TLX was also able to distinguish single- and dual-task conditions (Dey and Mann 2010), although it could not distinguish between memory and tracking tasks.

Although some studies show a direct relationship between subjective ratings of workload and task performance, others showed dissociations between the two measures (Hancock 1996; Oron-Gilad et al. 2008; Yeh and Wickens 1988). According to Yeh and Wickens, dissociations between workload from the task and performance can occur under conditions of underload and overload. In the case of underload, increased incentives or feedback can produce improvements in performance, although the task load itself stays the same. Later writers have reframed the incentive conditions as actually adding to the effective load (Guastello, Boeh et al. 2012), although the extent to which the contextual factors influence TLX ratings of a task is an open question and probably related to the instructions given to the study participants. In the case of growing overload, operators expend additional effort up to a point to maintain performance; within this region workload and performance are dissociated. When load exceeds a critical point, however, performance drops suddenly; hence performance and workload are re-associated (Hancock and Warm 1989 Han; Yeh and Wickens 1988).

Theoretical Issues in Ergonomics Science, Vol. 16, No. 1 (2015): pg. 20-52. DOI. This article is (C) Taylor \& Francis and permission has been granted for this version to appear in e-Publications@Marquette. Taylor \& Francis does not grant permission for this article to be further copied/distributed or hosted elsewhere without the express permission from Taylor \& Francis. 
TLX-performance relationships can be affected by operators' skill level. Those with stronger skills would rate a task lower in load. Those with greater skill would have greater automaticity in their cognitive processes, and thus a greater flexibility for coping with increases in workload (Oron-Gilad et al. 2008).

TLX-performance relationships can be affected by feedback from the task and the different ways in which operators could interpret that feedback. Feedback could refocus attention on skill development and away from some aspects of the workload (Oron-Gilad et al. 2008). According to self-efficacy theory, some people would see the gap between desired and actual performance as a signal to try harder or try differently. Others would just resign themselves to the present situation and regard the added effort as pointless or not worth the effort (Bandura and Locke 2003). According to perceptual control theory, feedback could sustain present performance and a lessening of effort (Vancouver 2005; Vancouver et al. 2002), and thus reduced TLX workload. This avenue toward complacency would result in lower performance when the demands increase, but also even when they do not increase.

The advantages of cognitive automaticity do not necessarily translate into advantages for using machine automation. Yeh and Wickens (1988) gave an example of a tracking task that was demanding in its original form, but when it was automated the cognitive load shifted to executive functions of working memory required to manage the automated system. Thus the workload-performance relationship in tracking seemed consistent and reduced, but the load demand shifted to a new aspect of performance.

In summary, the dissociation between workload and performance can result from several sources including appraisal of one's ability to perform under great load demands, motivation to invest effort, influences from the environment that are non-central to a particular task, the composition of cognitive and psychomotor resources contributing to workload, the tendency to maintain stability of performance under increased load conditions to the extent possible, and individual differences in how all these aspects are interpreted by an individual. Thus the present study was designed to explore the connection between some individual differences in elasticity-rigidity and TLX and the relationship between both groups of variables and performance.

\subsection{Anxiety}

Clinically, anxiety is often characterised as an irrational fear, but it could also originate from apprehension about genuine threats from the environment (Eysenck 1997;

Theoretical Issues in Ergonomics Science, Vol. 16, No. 1 (2015): pg. 20-52. DOI. This article is (C) Taylor \& Francis and permission has been granted for this version to appear in e-Publications@Marquette. Taylor \& Francis does not grant permission for this article to be further copied/distributed or hosted elsewhere without the express permission from Taylor \& Francis. 
Zeidner and Matthews 2011). It does, however, involve a modicum of arousal to the sympathetic nervous system. Anxiety presents with a variety of pathological conditions. Anxiety is often manifest as psychosomatic symptoms (Taylor 1953) - shaking arms and legs, nightmares, cold perspiration, eating and sleeping disruptions, diarrhoea or constipation, headaches, nausea - that as a group do not go together medically. If a person exhibits too many of the symptoms, then anxiety is concluded rather than, say, medical syndromes involving headaches, vision, or digestive track issues. Anxiety can result from the individual's personal level of adjustment or prolonged exposures to stress, although it is understood that stress itself does not affect all people the same way even if it were severe; individual coping strategies can be very effective.

Anxiety is often observed or experienced as a consequence of job stress. Job stressors variously include workload and time pressure, stressors with social origins such as job insecurity, or those with physical origins such as noise, heat, cold, shift work, and physical danger sources (Quick, Murphy, and Hurrell 1992). It could be transient, arriving and disappearing as the stress sources come and go, or it could be a longer term effect. Longer term effects might reflect personality traits, but could also reflect long-term job exposures, particularly if anxiety levels are widespread in the work group.

Anxiety can act on some, but not necessarily all, stages of cognitive processing (Zeidner and Matthews 2011). Tasks can be expected to differ regarding which stages of processing are most susceptible to disruptions from anxiety. Anxiety can also lead to behavioural disruption such as when a person is properly engaged in a task, but anxiety intrudes and disrupts the behaviour sequence. The interruption could be acute in the sense of dropping everything to make a quick exit from the task, perhaps to respond to a distraction, or hesitating at a critical moment and causing an error (Leary 1990; Murphy, DuBois, and Hurrell 1986).

Anxiety could be positively related to performance in some contexts, however, if there is a need to detect danger signals (Ein-Dor et al. 2010). More anxious people would tend toward a lower threshold to respond. A related interpretation is that anxious people engage in compensatory efforts to maintain performance goals, which would seem to apply to a broad range of tasks (Matthews et al. 2000; Szalma 2008). According to Vytal et al. (2012), however, anxiety is more likely to have a negative effect on performance if workload is low because the opportunities for ruminations are greater, but higher cognitive demands suppress the effects of anxiety.

Theoretical Issues in Ergonomics Science, Vol. 16, No. 1 (2015): pg. 20-52. DOI. This article is (c) Taylor \& Francis and permission has been granted for this version to appear in e-Publications@Marquette. Taylor \& Francis does not grant permission for this article to be further copied/distributed or hosted elsewhere without the express permission from Taylor \& Francis. 
Anxiety was tested as an elasticity (rigidity) variable in a recent cognitive workload and fatigue study (Guastello, Boeh, Shumaker et al. 2012) in which the participants performed an episodic memory task that had automatically increased load as the participant proceeded; it did not make the intended contribution to the model. It did work as an elasticity variable, however, in a different type of memory task, in which the participants competed against other participants for extra class credits (Guastello, Boeh, Schimmels et al. 2012 ). Anxiety also showed a similar dynamical impact on individual accident involvements in a manufacturing setting, such that people reporting higher levels of anxiety had experienced notably more or fewer accidents than others, given the same range of hazard exposures (Guastello 2003; Guastello and Lynn, forthcoming). Anxiety thus acted as a source of rigidity; at low to moderate hazard levels it had a positive effect on safety, perhaps because of the increased effort expended in scanning the environment. At the highest levels of hazard, however, its effect was negative probably for the same reason: too much scanning and deliberating and not enough immediate adaptive action. The foregoing results suggest that the effects of anxiety depend on situational constraints and may be social in origin, at least in part, as Leary and Kowalski (1995) suggested.

Anxiety is a facet of the broader personality trait neuroticism, which includes emotional stability and reactivity (Costa and McCrae 1992). Cox-Fuenzalida et al. (2004) assessed the role of neuroticism in response to increasing or decreasing workloads in an auditory vigilance task. Participants who were higher in neuroticism showed longer response times in both conditions and more errors in the condition where speed increased. In addition to the explanations for the anxiety-performance relationships already given, anxious people appear to cope less effectively with increased demands. Workload levels are discussed further in Section 1.8.

Szalma and Taylor (2011) constructed a vigilance task where participants worked under different combinations of automation levels (machine versus manual control) and reliability of automation. Five factor model (FFM) traits were not consistently related to performance or TLX ratings across all conditions, but neuroticism was correlated with perceived temporal demands in one of the more challenging combinations of automation and reliability. Rose et al. (2002) found neuroticism correlated with perceived frustration in a vigilance task.

\subsection{Conscientiousness}

Conscientiousness is a personality trait whereby someone with a high score would be attentive to details in their work and daily life, adherent to rules and regulations, and

Theoretical Issues in Ergonomics Science, Vol. 16, No. 1 (2015): pg. 20-52. DOI. This article is (C) Taylor \& Francis and permission has been granted for this version to appear in e-Publications@Marquette. Taylor \& Francis does not grant permission for this article to be further copied/distributed or hosted elsewhere without the express permission from Taylor \& Francis. 
would do their best to complete a job properly (Cattell, Eber, and Tatsuoka 1970). Defined in this fashion it is a primary trait in the context of the 16 Personality Factors Questionnaire (16PF). The personality construct of the same name from the Five-Factor Model includes the foregoing definition plus another primary trait, self-controlled versus uncontrolled or impulsive (Conn and Rieke 1994). The research evidence now suggests that the primary and more narrowly defined traits are more closely linked to task performance than the broader traits (Dudley et al. 2006; Guastello et al. 2013; Szymura 2010).

The definition of conscientiousness suggests that it would be relevant to a wide range of jobs and tasks. This point is basically true (Meyer, Dalal, and Bonaccio 2009), although some researchers have found that conscientiousness only has a positive impact on performance when the overall emotional climate of the workplace is positive, and could be negative otherwise (Byrne et al. 2005; Meyer, Dalal, and Bonaccio 2009). Others have reported that there could be limits to the effectiveness of conscientiousness in some circumstances, such that there is an optimal level for performance, but very high scores could be counterproductive; in Cattell, Eber, and Tatsuoka's (1970) taxonomy, the opposite of conscientiousness is expedience which places value on getting things done in a reasonable amount of time.

People scoring higher in conscientiousness are capable of focusing their attention to a greater extent than others; this attribute has been characterised as 'rigidity' (MacLean and Arnell 2010). It would follow that conscientiousness could act as a source of rigidity in workload studies as well, such that the performance of the conscientious person would be less negatively affected by stressors from the task, at least up to a critical point at which their error rates would be greater than those of others. Impulsivity, in contrast, denotes an element of elasticity and spontaneity in response to unplanned events. Research that specifically connected conscientiousness to vigilance tasks showed that conscientious participants were more sensitive to the visual targets and made fewer false alarms than others (Rose et al. 2002). In another situation, conscientious participants reported greater workload ratings for a challenging combination of automation and automation reliability than other participants, and lower ratings of workload than others for a less challenging combination (Szalma and Taylor 2011). The present study investigated whether conscientiousness would be reflected in the TLX ratings, particularly for performance pressure and effort.

Theoretical Issues in Ergonomics Science, Vol. 16, No. 1 (2015): pg. 20-52. DOI. This article is (C) Taylor \& Francis and permission has been granted for this version to appear in e-Publications@Marquette. Taylor \& Francis does not grant permission for this article to be further copied/distributed or hosted elsewhere without the express permission from Taylor \& Francis. 
NOT THE PUBLISHED VERSION; this is the author's final, peer-reviewed manuscript. The published version may be accessed by following the link in the citation at the bottom of the page.

\subsection{Work ethic}

The Protestant work ethic (PWE) is a work value, or set of beliefs about work, that emphasises independent action and an obligation to work (Buchholz 1977; Furnham 1990). A person who endorses the work ethic would agree with statements that emphasise independent action and obligation to work such as 'work is good regardless of how hard or boring it is' and 'a person should avoid dependence on others.' They are likely to maintain effort on boring or tedious tasks (Greenberg 1977).

There was a time when PWE was the dominant belief system in western culture, particularly in the USA, but concerns were raised in the late 1970s that it was no longer the dominant belief system (Buchholz 1977). Alternative belief systems would be the humanistic system ('work should be meaningful'), the Marxist exploitive system ('management exploits workers'), the Marxist participative system ('workers should have a voice in decisions'), and the leisure system ('work is necessary to live, but real life exists outside the work place'). PWE still exists, nonetheless, particularly its aspect of independence when it is combined with other beliefs about free will (Stillman et al. 2010). In the case of workload studies, PWE could reasonably have the same relationship to performance as conscientiousness and might also affect TLX ratings for the same reason.

\subsection{Emotional intelligence}

Salovey and Mayer (1990) introduced the concept of EI as 'a type of emotional information processing that includes accurate appraisal of emotions in oneself and others, appropriate expression of emotion, and adaptive regulation in such a way as to enhance living' (Mayer 2001). Mayer and Salovey (1997) refined the definition to reflect more strongly that EI was the ability 'to perceive accurately, appraise, and express emotion; the ability to access and/or generate feelings when they facilitate thought; the ability to understand emotion and emotional knowledge; and the ability to regulate emotions to promote emotional and intellectual growth' (Mayer 2001). The two definitions promoted different measurement models, some of which emphasised the cognitive aspect of EI, while others emphasised personality aspects of EI (Cherniss 2010).

Although EI was touted as a very promising construct for personnel selection, some researchers reported difficulty finding any predictive value in it beyond what was accounted for by general intelligence and conscientiousness (Amelang and Steinmayr 2006). Others found evidence that it moderated the relationship between conscientiousness and work performance such that conscientiousness positively predicts

Theoretical Issues in Ergonomics Science, Vol. 16, No. 1 (2015): pg. 20-52. DOI. This article is (C) Taylor \& Francis and permission has been granted for this version to appear in e-Publications@Marquette. Taylor \& Francis does not grant permission for this article to be further copied/distributed or hosted elsewhere without the express permission from Taylor \& Francis. 
work performance if EI is also high, and negatively predicts performance otherwise (Douglas, Frink, and Ferris 2004). A later meta-analysis, however, reported generalisable correlations between .24 and .30 between EI and work performance, noting that the better results came from personality-based measures rather than cognitive ability measures (O’Boyle et al. 2011).

If high workload is producing high stress and the potential for emotional reactions, people with higher EI should have the ability to detect those reactions and mitigate the situation effectively (Thompson 2010). Thompson also invoked the cusp model for workload with its elasticity-rigidity construct as part of his exposition. Low EI was associated with rigidity. Although indifference to one's own emotions may facilitate focus of attention instead of distractibility, the indifference to one's own stress reactions is an important reason why smart people make catastrophically bad decisions, according to Thompson. Rigidity can buffer against performance variation when workload is low to moderate, but can lead to catastrophic failure when workload is high. The role of EI might only be important in high-stress jobs or jobs where a substantial amount of emotional labour is involved, according to Joseph and Newman (2010).

The measurement model adopted in the present study was the version by Schutte et al. (1998), which is a personality-based construct that captures the ability to interpret one's emotions and responsiveness to the emotions of others. Schutte et al.'s measure was also conveniently brief for a study that involved measuring a number of variables, a core task that was meant to be time consuming, and time constraints on the participants' availability. Although it was expected that EI could influence TLX ratings of a given situation, it was not easy to say a priori whether EI would result in lower TLX ratings because the individual was more comfortable handling the demands or higher ratings because the individual was more sensitive to what was taking place. Thus in the present experiment, knowledge of one's own emotions and the regulation thereof are intrinsic to working alone or with other people. Recognition of co-workers' states and response thereto should facilitate collective efforts.

\subsection{Group effects}

Another unresolved problem in cognitive workload research is that the research situations typically involve observations of or from individuals who are working alone. The question was raised (Funke et al. 2012), however, about how to calibrate workload for an entire team. Although researchers use standard physiological and subjective measures, there is no consensus about how to combine them within a team. Group dynamic processes

Theoretical Issues in Ergonomics Science, Vol. 16, No. 1 (2015): pg. 20-52. DOI. This article is (C) Taylor \& Francis and permission has been granted for this version to appear in e-Publications@Marquette. Taylor \& Francis does not grant permission for this article to be further copied/distributed or hosted elsewhere without the express permission from Taylor \& Francis. 
are inevitably involved in addition to the sum of the loads on individuals (Cooke et al. 2012; Stevens et al. 2013). People switch tasks, cover for each other, and coordinate. Although these cooperative behaviours are usually expected to produce positive effects on performance, sometimes the opposite occurs (Barnes et al. 2008; Stachowski, Kaplan, and Waller 2009). The presence of others, the depth of the interactions among participants on the task, the complexity of the task, and evaluation apprehension can have positive, negative, or interactive effects on group performance (Bond and Titus 1983; Hertel, Kerr, and Messé 2000). For problem-solving groups, the group performance is better than the most competent individual only about half of the time (Shepperd 1993). The group is more likely to perform better when there is a critical mass of people to contribute (Dennis and Valacich 1993; Guastello 2010). In addition, the effects of anxiety on performance are more likely to be visible when the individual is performing in front of an audience or working with other people interactively, particularly if some sort of evaluation were involved (Leary and Kowalski 1995).

This study thus included experimental conditions whereby people worked alone or in pairs. This difference could lower the TLX ratings for workload under the principle that 'many hands make light the work.' On the other hand it could increase TLX ratings if working with another person added a new source of stress.

\subsection{Effect of speed}

The effect of speed stress is related to load in that load and speed interact to produce increases in errors (Conrad 1951). The speed-accuracy trade-off is also well known (Kantowitz and Sorkin 1983; Szalma and Teo 2012). Increases in work speed (but not load per se) generally do not produce increases in errors until the speed demand reaches a critical point, after which errors increase suddenly. This basic rule is mitigated to some extent by other properties of the task. In a vigilance task the rate of target events has a substantial impact on performance (Warm and Jerison 1984). In this study, however, the target event rate was held constant, but the speed of changing stimuli with and without targets was increased or decreased to manipulate speed stress. In a study conducted in parallel to the present one (Guastello, Malon et al. 2013), speeding up across three different stimulus rates produced more miss errors overall than slowing down over the same three rates. Cox-Fuenzalida et al. (2004) found a similar result for participants with high neuroticism. Thus the speed change manipulation was expected to produce changes in TLX ratings as well, particularly ratings of temporal demand.

Theoretical Issues in Ergonomics Science, Vol. 16, No. 1 (2015): pg. 20-52. DOI. This article is (C) Taylor \& Francis and permission has been granted for this version to appear in e-Publications@Marquette. Taylor \& Francis does not grant permission for this article to be further copied/distributed or hosted elsewhere without the express permission from Taylor \& Francis. 


\subsection{Hypotheses}

The hypotheses were that anxiety, conscientiousness, PWE, EI, and the experimental manipulation of working alone versus working in pairs would all be correlated with some of the TLX scales, and both groups of variables would explain performance on the two tasks to some extent.

1. The experimental manipulation of working alone or in pairs would affect TLX ratings and performance in either a positive or negative direction. The experimental conditions of working alone or in pairs were tested as a dummy-coded variable in a regression analysis.

2. The experimental manipulation of speeding up or slowing down would affect TLX ratings and performance such that speeding up would result in higher workload ratings. This pair of experimental conditions was also tested as a dummy-coded variable in a regression analysis.

3. Anxiety, conscientiousness, work ethic, and EI would account for unique portions of the variance in TLX ratings. The extant literature does not provide a clear indication of how these variables would combine to produce positive or negative regression weights.

4. The foregoing variables were competitively tested for their ability to explain performance on the vigilance task and the secondary task.

5. The measure of conscientiousness that was used for testing the second and third hypotheses was separated into two contributing facets; one was a narrower definition of conscientiousness that was more consistent with the 16PF scale of the same name (factor G; Cattell 1994; Cattell, Eber, and Tatsuoka 1970) and the other was impulsivity versus control, which was similar to 16PF factor Q3 (Cattell 1994; Cattell, Eber, and Tatsuoka 1970). The analytic strategy adopted here was to first assess the role of conscientiousness in the broader definition of the Five-Factor Model, and then separate the construct into the two narrower constructs to determine if doing so would produce different results.

6. In light of previous research showing that the effects of anxiety often take shape in threatening conditions or in uncertain interactions with other people, interaction effects were tested for anxiety with working alone or in pairs. Both performance and TLX ratings were used as dependent measures.

7. Inasmuch as the construct of EI emphasises effective interactions with other people, interaction effects were tested for the combination of EI and working alone or in pairs. Again, both performance and TLX ratings were used as dependent measures.

Theoretical Issues in Ergonomics Science, Vol. 16, No. 1 (2015): pg. 20-52. DOI. This article is (C) Taylor \& Francis and permission has been granted for this version to appear in e-Publications@Marquette. Taylor \& Francis does not grant permission for this article to be further copied/distributed or hosted elsewhere without the express permission from Taylor \& Francis. 


\section{Method}

\subsection{Participants and tasks}

Participants were 141 undergraduates, aged 18-22, who were enrolled in psychology courses, of whom $40 \%$ were male. Participants performed the experimental tasks individually or in pairs; there were 47 individuals and 47 pairs that produced an effective $n$ of 94 . Participants completed two timed tests and an untimed questionnaire totalling 25 minutes before performing the main experimental task. The timed tests were not involved in the present study and are not discussed further.

The main experimental task was to monitor a computer screen with a $33-\mathrm{cm}$ diagonal monitor while completing a 300-piece jigsaw puzzle. Participants were seated at a table $2.0 \mathrm{~m}$ long and $0.9 \mathrm{~m}$ wide. They were initially positioned in the location shown in Figure 2, and usually stayed there, although they were not prohibited from moving about or from using all the table space to work on the puzzle. The bell started in the position shown in Figure 1, but they were not prohibited from moving it around.

Figure 2. Workspace layout for vigilance and puzzle tasks.

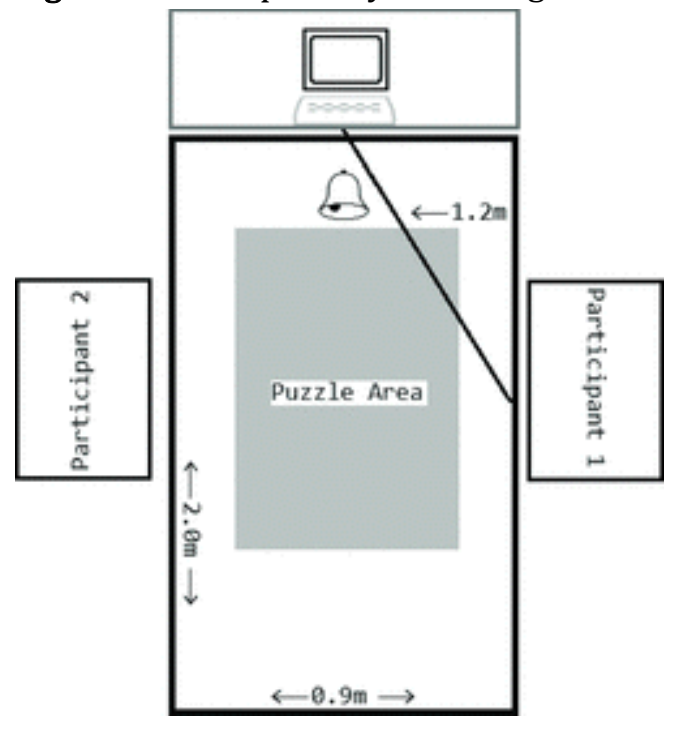

Participants were given the following instructions at the beginning of their experimental session:

In this experiment you will be completing a couple timed tests, an untimed questionnaire, and the central experimental tasks. The two central tasks are done

Theoretical Issues in Ergonomics Science, Vol. 16, No. 1 (2015): pg. 20-52. DOI. This article is (C) Taylor \& Francis and permission has been granted for this version to appear in e-Publications@Marquette. Taylor \& Francis does not grant permission for this article to be further copied/distributed or hosted elsewhere without the express permission from Taylor \& Francis. 
simultaneously: You will complete a jigsaw puzzle while watching a security camera video on the computer screen. Let's look at a demo version of the security cam video.

The next instruction was part of the demo: 'You'll see empty rooms most of the time, but occasionally you'll see people running through the room apparently up to no good. When you see intruders running through, ring the bell.' The spoken narrative continued: 'Meanwhile, your other goal is to complete as much of the puzzle as possible in the time allotted.'

Further instructions were given to those who were working in pairs: 'You should both be responsible for completing the puzzle and monitoring intruders.' This instruction was intended to deter them from separating the two tasks so that one only watched the screen and the other assembled the puzzle. They were not given any limitation about talking or how to work together. Some pairs did not talk. Some pairs kept their talk task related and made clear indications that they were performing both tasks together as instructed. Some pairs kept their conversation running for most of the work period on both task-related and unrelated topics.

The screen program was produced with Steam virtual reality software (Valve Corporation 2011). It showed scenes from seven rooms in an office building environment in rotation. The target images consisted of a character that was designed to appear dangerous. The target character could appear in any of the seven virtual rooms, and he was in motion when he appeared. Still frames of a non-target scene and a target scene appear in Figure 3. The rooms were displayed singly, full screen, in three blocks of 30 minutes each at 2 screens/min, 4 screens/min, and 8 screens/min. Targets appeared on the screen at random intervals of 1-7 seconds. Targets appeared in $10 \%$ of the scenes in each of the three speed conditions. The target trials were randomly distributed through the blocks of trials. Participants rang a desk bell when they saw a target.

Figure 3. Still frames from vigilance program with and without an intruder.

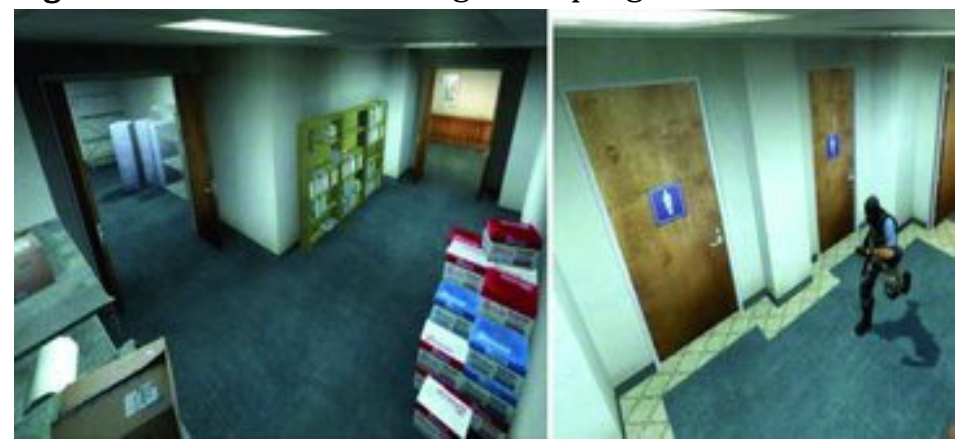

Theoretical Issues in Ergonomics Science, Vol. 16, No. 1 (2015): pg. 20-52. DOI. This article is (C) Taylor \& Francis and permission has been granted for this version to appear in e-Publications@Marquette. Taylor \& Francis does not grant permission for this article to be further copied/distributed or hosted elsewhere without the express permission from Taylor \& Francis. 
Approximately half of the experimental sessions were prepared with the slow condition first and followed by the medium speed condition and the fast speed condition. The other half was prepared with the fast condition first, followed by medium and slow conditions. Prior to the data collection, participants were given a brief instruction regarding the nature of the task, examples of intruders, and when to ring the bell. An experimenter who was in the room followed a script that listed the time of the appearance of target and non-target screens. When the bell rang, the experimenter recorded a correct hit, a miss, or a false alarm. The latter two indices were used in the experimental analysis here.

The puzzle was a realistic-style image of a red fox in the foreground on snowy terrain and a European town with eighteenth-century architecture in the background. The picture of the image that appeared on the puzzle box cover remained available to the participants while working on the puzzle. A second puzzle depicting the solar system, also 300 pieces, was available in case a participant or pair of participants actually finished the fox puzzle.

\subsection{Measurements}

Before proceeding to the main tasks, participants completed a 5-minute timed test of arithmetic ability, a 5-minute timed test of spelling ability, and an untimed survey instrument measuring anxiety, conscientiousness, PWE, and EI. The same versions of arithmetic and spelling tests were used in prior studies on cognitive workload and fatigue (Guastello, Boeh et al. 2012; Guastello, Boeh et al. 2013). Because they did not have any impact on the analyses in this study, they are not described further here.

The anxiety test was a variation of Taylor Manifest Anxiety Scale (Taylor 1953) that was used in earlier research on cognitive workload and fatigue (Guastello, Boeh, Schimmels et al. 2012; Guastello, Boeh, Shumaker et al. 2012; Guastello, Boeh et al. 2013). It consisted of 19 statements such as 'I have nightmares about my job or classes.' The participant responded by checking 'agree' (2 points), '?' (meaning 'unsure' or 'do not know,' 1 point), or 'disagree' (0 points). Some items were reverse scored. Reliability was assessed with Cronbach's alpha for international consistency. The $\alpha$ value was .75 in the earlier study and .64 in this study; some of the symptoms apparently had more variance in the previous sample than they did in the present sample.

The PWE scale consisted of nine items from Buchholz (1977) to which the participant responded by checking 'strongly disagree' $=1$, 'disagree' $=2$, '?' (meaning

Theoretical Issues in Ergonomics Science, Vol. 16, No. 1 (2015): pg. 20-52. DOI. This article is (C) Taylor \& Francis and permission has been granted for this version to appear in e-Publications@Marquette. Taylor \& Francis does not grant permission for this article to be further copied/distributed or hosted elsewhere without the express permission from Taylor \& Francis. 
'unsure' or 'do not know') =3, 'agree' $=4$, or 'strongly agree' $=5$. An example item was the following: 'A person must depend on himself to get ahead.' Some items were reverse scored. $(\alpha=.50)$.

The EI scale was the 33-item scale developed by Schutte et al. (1998). The participants responded using the same five-point Likert scale that was used for PWE, and some items were reverse scored here as well $(\alpha=.82)$. An example item was the following: 'When I am faced with obstacles, I remember times when I faced similar obstacles and overcame them.'

Conscientiousness was composed of 20 items drawn from the International Personality Item Pool (Goldberg 2011). The items represented the narrower (surface or primary trait) concept of conscientiousness, such as 'I push myself very hard to succeed,' and the impulsivity component that is part of the broader definition of the construct, such as 'I do things without thinking of the consequences.' The participants responded using the same five-point Likert scale that was used for PWE, and some items were reverse scored here as well $(\alpha=.84)$.

After the main tasks, the participants completed the TLX ratings using a paper-andpencil format and a 21-point rating scale (NASA Ames Research Center, n.d.). Scales were anchored as 1 = 'very low' and 21 = 'very high.'

The experimental condition for working alone or in pairs was used as a dichotomous variable in the statistical analysis. Similarly, the experimental condition for working at the slow speed first versus fast speed first was used as another dichotomous variable.

There was a dependent measure for performance on each task. The score on the security camera task was the sum of three rates of miss errors across the three speed conditions. The total scores could thus range from 0.00 to 3.00. Because false alarms rates were very low and non-existent for most participants, false alarms were not analysed here. Summing the rates gave equal weight to the three speed conditions.

Performance on the puzzle was measured as the total number of pieces assembled by the end of the 90-minute period. Aggregates of four pieces that were assembled in addition to the main part of the puzzle completion were treated as 'assembled.'

Theoretical Issues in Ergonomics Science, Vol. 16, No. 1 (2015): pg. 20-52. DOI. This article is (c) Taylor \& Francis and permission has been granted for this version to appear in e-Publications@Marquette. Taylor \& Francis does not grant permission for this article to be further copied/distributed or hosted elsewhere without the express permission from Taylor \& Francis. 
NOT THE PUBLISHED VERSION; this is the author's final, peer-reviewed manuscript. The published version may be accessed by following the link in the citation at the bottom of the page.

\subsection{Analyses}

Stepwise multiple regression was used to test hypotheses 1-5 connecting the four elasticity variables and two experimental manipulations with TLX scales. In addition, stepwise multiple regression analyses were used to test anxiety, conscientiousness, EI, PWE, the two experimental conditions, and the TLX scales competitively for their ability to predict performance on each task.

The choice of forward, backward, or stepwise analyses involves a trade-off between including an extraneous variable in the model (type I error), missing a variable that could be highly correlated with another variable that is included in the model (type II error), statistical power associated with individual weights, and the generalisability of $R$ and the final model (Babyak 2004; Darlington 1990; Derkson and Kelseman 1992; Thompson 1995). The generalisability of the final model depends on the number of variables in the model (fewer is better), sample size (larger is better), and sampling differences between the calibration model and new samples to which one wants to generalise.

The rules of thumb for determining appropriate sample sizes, 7-10 cases per variable, appear to be well reasoned (Green 1991; Babyak 2004). For the models used here with TLX variables criteria, which used seven predictors, the cases/variables ratio is 18:1 prior to analysis (cf. Cohen 1990), after discounting cases with missing data. For the models with performance criteria and TLX scales included as predictors, the cases/variables ratio is 9.8 prior to analysis. The multiple regression results, reported below, did not contain more than five variables; the cases/variables ratio after the fact was 31.8 .

It is important to recognise that the study was not a data mining exercise. All variables had theoretical relevance, and discerning their relative importance with respect to various criteria was meaningful. If any were left out of a multiple regression model because of multicollinearity with another variable, rather than simple inability to correlate, it would be possible to detect those conditions with the bivariate correlations that are also presented.

In a subsequent set of analyses for hypothesis 6 , conscientiousness was separated into two constructs to determine if doing so would produce different results. There were two possible strategies for separating sub-constructs or facets within conscientiousness. One is to use factor analysis and separate them empirically if possible. The alternative would require the experimenters to separate the questionnaire items based on judgements

Theoretical Issues in Ergonomics Science, Vol. 16, No. 1 (2015): pg. 20-52. DOI. This article is (C) Taylor \& Francis and permission has been granted for this version to appear in e-Publications@Marquette. Taylor \& Francis does not grant permission for this article to be further copied/distributed or hosted elsewhere without the express permission from Taylor \& Francis. 
of item content. The facets that are usually associated with the FFM were produced in this fashion (Cattell and Mead 2008).

An attempt to separate conscientiousness through factor analysis did not produce useful results. The principal axis factoring method produced four factors with an initial $\lambda>$ 1.0. Two of the factors showed $\lambda>1.0$ after rotation using the direct oblimin method. Principal axis factoring was used instead of components analysis to avoid an overly large first factor that included all or most items. Oblique rotation was used because in theory primary traits are independent but somewhat correlated (Cattell, Eber, and Tatsuoka 1970).

The factor analysis was regrettably unsuccessful because all items displayed their highest loadings on the first factor. Attempts to interpret the other factors (with loadings greater than .30) did not produce a construct resembling impulsivity. As a result, the items were separated into two groups based on judgements of the item content; one group contained impulsivity items and the others were aggregated into a more restricted construct of conscientiousness. The latter were labelled 'primary conscientiousness' for present purposes. The impulsivity items were as follows: 'I often leave a mess in my room.' 'I do things without thinking of the consequences.' 'I make plans and stick to them.' 'I prefer to just let things happen.' 'I continue until everything is perfect.' 'I do things according to a plan.' The impulsivity items were keyed so that high scores represented control and low scores represented impulsivity. The correlation between the two constructs was .70 ( $p$ $<.001)$.

The analyses just described do not test the elasticity principle explicitly. To do so, the mathematical models shown in Figure 1 and a specific form of analysis would be required along with behavioural indicators of workload and behavioural outcomes that are measured at two or more points in time (Guastello 2011, 2013). The use of the two cusp catastrophe models would also allow for the separation of workload and fatigue effects, which are potentially conflated in the TLX scales the way they are usually used.

The interaction hypotheses were tested through multiple regression. The interaction terms were composed by dividing each contributing variable by its standard deviation before multiplying the two together. This procedure eliminates biasing the interaction effect by the variable with the larger standard deviation (Evans 1991).

Theoretical Issues in Ergonomics Science, Vol. 16, No. 1 (2015): pg. 20-52. DOI. This article is (C) Taylor \& Francis and permission has been granted for this version to appear in e-Publications@Marquette. Taylor \& Francis does not grant permission for this article to be further copied/distributed or hosted elsewhere without the express permission from Taylor \& Francis. 


\section{Results}

Descriptive statistics for the research variables appear in Table 1. Bivariate correlations among the psychosocial variables are given in Table 2 . Anxiety was not correlated with conscientiousness, which was consistent with the factorial independence between the two constructs that is now a widespread result in personality theory and research. However, anxiety was unexpectedly correlated with PWE such that PWE was higher among anxious people; it had previously seemed more likely that PWE would be correlated with conscientiousness instead. EI was significantly correlated with conscientiousness and PWE.

Table 1. Descriptive statistics.

\begin{tabular}{|l|l|l|l|l||}
\hline Variable & \multicolumn{1}{|c|}{ Minimum } & \multicolumn{1}{|c|}{ Maximum } & \multicolumn{1}{|c|}{$\boldsymbol{M}$} & \multicolumn{1}{|c|}{ SD } \\
\hline \hline Anxiety & 2.00 & 26.11 & 11.51 & 5.71 \\
\hline Conscientiousness & 39.00 & 91.00 & 69.33 & 10.29 \\
\hline Work ethic & 17.00 & 34.00 & 26.10 & 3.57 \\
\hline \hline Emotional intelligence & 90.00 & 162.00 & 128.02 & 11.43 \\
\hline TLX ratings & 1.00 & 21.00 & 13.62 & 3.96 \\
\hline Mental demand & 1.00 & 18.00 & 3.52 & 3.10 \\
\hline Physical demand & 1.00 & 20.00 & 10.94 & 4.68 \\
\hline Temporal demand & 2.00 & 19.00 & 11.54 & 3.82 \\
\hline Performance & 3.00 & 21.00 & 13.36 & 3.94 \\
\hline Effort & 1.00 & 21.00 & 11.16 & 5.38 \\
\hline Frustration & & & \\
\hline Performance & 0.00 & 2.40 & 0.76 & 0.43 \\
\hline Sum of miss error rates & 8.00 & 359.00 & 181.36 & 67.86 \\
\hline \hline Puzzle pieces assembled & & & \\
\hline
\end{tabular}

Table 2. Correlations among psychosocial variables.

\begin{tabular}{|l|l|l|l||}
\hline & $\mathbf{2}$ & \multicolumn{1}{|c|}{$\mathbf{3}$} & \multicolumn{1}{|c|}{$\mathbf{4}$} \\
\hline (1) Anxiety & -.12 & -.13 & $.26^{* *}$ \\
\hline (2) Conscientiousness & & $.34^{* * *}$ & .07 \\
\hline (3) Emotional intelligence & & & $.20^{* *}$ \\
\hline \hline (4) Work ethic & & & \\
\hline
\end{tabular}

Bivariate correlations among the TLX measurements appear in Table 3. Most scales were correlated with most other scales. This result is consistent with the use of TLX as a

Theoretical Issues in Ergonomics Science, Vol. 16, No. 1 (2015): pg. 20-52. DOI. This article is (C Taylor \& Francis and permission has been granted for this version to appear in e-Publications@Marquette. Taylor \& Francis does not grant permission for this article to be further copied/distributed or hosted elsewhere without the express permission from Taylor \& Francis. 
single measurement in some past research (Byers, Bittner, and Hill 1989; Dey and Mann 2010; Dickinson, Byblow, and Ryan 1993; Noyes and Bruneau 2007).

Table 3. Correlations among TLX scales.

\begin{tabular}{|c|c|c|c|c|c|}
\hline & 2 & 3 & 4 & 5 & 6 \\
\hline (1) Mental & $.22^{* *}$ & $.42^{* * *}$ & .08 & $.27^{* * *}$ & $.34 * * *$ \\
\hline (2) Physical & & $.33^{* * *}$ & .18 & .11 & $.27^{* * *}$ \\
\hline (3) Temporal & & & $.31^{* * *}$ & $.37^{* * *}$ & $.38^{* * *}$ \\
\hline (4) Performance & & & & $.24^{* *}$ & -.04 \\
\hline (5) Effort & & & & & .12 \\
\hline (6) Frustration & & & & & \\
\hline
\end{tabular}

\subsection{Individual difference in TLX ratings}

Bivariate correlations among the TLX scales and psychosocial variables appear in Table 4. Anxiety was positively correlated with temporal demand and frustration. EI was positively correlated with performance demand and effort. PWE was positively correlated with frustration. Conscientiousness was not correlated with any of the TLX scales.

Table 4. Correlations between TLX and psychosocial variables.

\begin{tabular}{|l|l|l|l||l||}
\hline & Anxiety & \multicolumn{1}{|c|}{ Conscientiousness } & Emotional intelligence & Work ethic \\
\hline \hline Mental & .11 & .11 & .15 & .05 \\
\hline Physical & .08 & -.10 & .03 & .05 \\
\hline Temporal & $.18^{*}$ & .08 & .12 & .09 \\
\hline Performance & .03 & .16 & $.30^{* * *}$ & .08 \\
\hline Effort & .15 & .01 & $.23^{* *}$ & $.17^{*}$ \\
\hline Frustration & $.22^{*}$ & .03 & .01 & \\
\hline
\end{tabular}

The multiple regression model for mental demand predicted by the four psychosocial variables and two experimental conditions contained only one significant correlate, which was EI $\left(r=.18 ; r^{2}=.03, t=1.99, p<.05, N=127\right)$. The difference between this result and the smaller correlation in Table 4 was produced by the listwise deletion of seven cases containing missing data in the multiple regression analysis.

None of the predictors entered the regression equation for physical demands. However, two variables entered the equation predicting temporal demand $\left(R=.33, R^{2}=\right.$ .11, adj. $\left.R^{2}=.09 ; F(2,124)=7.455, p<.001\right)$. People who worked in pairs and who 
were scored higher in anxiety reported greater temporal demand. The tests on the beta weights for the multiple regression analyses appear in Table 5.

Table 5. Multiple regression results for TLX, personality and psychosocial variables, and performance.

\begin{tabular}{|c|c|c|}
\hline Independent & $\beta$ & $t$ \\
\hline \multicolumn{3}{|c|}{ Dependent: TLX temporal demands } \\
\hline Working in pairs & 0.25 & $2.93^{* *}$ \\
\hline Anxiety & 0.21 & $2.47^{*}$ \\
\hline \multicolumn{3}{|c|}{ Dependent: TLX performance pressure } \\
\hline Emotional intelligence & 0.29 & $3.56^{* * *}$ \\
\hline Working in pairs & 0.28 & $3.41^{* * *}$ \\
\hline \multicolumn{3}{|c|}{ Dependent: TLX perceived effort } \\
\hline Emotional intelligence & 0.23 & $2.74^{* *}$ \\
\hline Task speed presented first & -0.22 & $-2.53^{*}$ \\
\hline \multicolumn{3}{|l|}{ Dependent: puzzle pieces } \\
\hline Working in pairs & 0.41 & $5.73^{* * *}$ \\
\hline TLX performance pressure & 0.40 & $5.52^{* * *}$ \\
\hline Work ethic & -0.16 & $-2.38^{*}$ \\
\hline TLX physical demands & -0.14 & $-2.06^{*}$ \\
\hline \multicolumn{3}{|c|}{ Dependent: total security camera misses } \\
\hline Working in pairs & -0.25 & $-3.07^{* *}$ \\
\hline Work ethic & 0.20 & $2.48^{*}$ \\
\hline Conscientiousness & -0.16 & $1.92^{\mathrm{a}}$ \\
\hline
\end{tabular}

People who gave higher ratings of performance pressure of the tasks scored higher in EI and also worked in pairs $\left(R=.41, R^{2}=.16\right.$, adj. $\left.R^{2}=.15 ; F(2,125)=12.25, p<.001\right)$. People who reported greater effort demands of the tasks also scored higher in EI and were in the experimental condition where the vigilance task started with the camera frames changing slowly with a concomitantly low absolute number of intruders and then progressed to frames changing faster $\left(R=.32, R^{2}=.10\right.$, adj. $R^{2}=.09 ; F(1,125)=7.24, p$ $<.001)$. Only one variable entered the equation predicting frustration, which was anxiety $\left(r=.23, r^{2}=.05, t=2.60, p<.05\right)$.

\subsection{Prediction of performance}

The bivariate correlation between total errors on the vigilance task and the puzzle was $-.18(p<.05)$, indicating that people who accomplished more of the puzzle also made fewer errors on the vigilance task. None of the TLX scales were correlated with 
NOT THE PUBLISHED VERSION; this is the author's final, peer-reviewed manuscript. The published version may be accessed by following the link in the citation at the bottom of the page.

performance on the vigilance task (Table 6). PWE was the only other variable in the set that was correlated with vigilance errors; people scoring high on PWE made more miss errors.

Table 6. Correlations between TLX and psychosocial variables with performance.

\begin{tabular}{|l|l|l||}
\hline \hline & \multicolumn{1}{|c|}{ Puzzle } & \multicolumn{1}{c|}{ Total vigilance miss errors } \\
\hline \hline Mental & -.03 & .06 \\
\hline Physical & -.10 & .05 \\
\hline Temporal & $.21^{*}$ & .05 \\
\hline Performance & $.47^{* * *}$ & -.11 \\
\hline Effort & .12 & .08 \\
\hline Frustration & -.10 & .09 \\
\hline Anxiety & -.04 & .01 \\
\hline Conscientiousness & $.20^{*}$ & -.17 \\
\hline Emotional intelligence & $.18^{*}$ & .05 \\
\hline Work ethic & -.15 & $.20^{* *}$ \\
\hline
\end{tabular}

However, the multiple regression model (Table 5) predicting vigilance errors contained three significant effects: working alone, PWE, and conscientiousness $\left(R=.37, R^{2}\right.$ $=.14$, adj. $\left.R^{2}=.12, F(3,132)=7.03, p<.001\right)$. The majority of the prediction was afforded by working alone (10\%); the latter two variables accounted for only $4 \%$ of the variance in vigilance errors.

The multiple regression model (Table 5) predicting puzzle completion contained four significant effects $\left(R=.66, R^{2}=.44\right.$, adj. $\left.R^{2}=.42, F(4,122)=23.97, p<.001\right)$. Once again the majority of the prediction was afforded by working alone (28\%), followed by TLX performance (11\%), PWE (3\%), and TLX physical demands (2\%). Physical demands appeared to be a suppressor effect. The tasks were clearly not physically demanding and the mean score for physical demands was much lower than the means for other TLX ratings. Some people did give ratings on physical demands as high as 18 .

\subsection{Separation of conscientiousness constructs}

Table 7 lists the bivariate correlations between the TLX scales and performance measures with conscientiousness, primary conscientiousness, and impulsivity versus control. The correlations for total miss errors in the vigilance task, puzzle completion, and temporal demands increased slightly when the impulsivity facet was removed. The correlation for temporal demands with impulsivity was significant $(r=.18, p<.05)$,

Theoretical Issues in Ergonomics Science, Vol. 16, No. 1 (2015): pg. 20-52. DOI. This article is (C) Taylor \& Francis and permission has been granted for this version to appear in e-Publications@Marquette. Taylor \& Francis does not grant permission for this article to be further copied/distributed or hosted elsewhere without the express permission from Taylor \& Francis. 
NOT THE PUBLISHED VERSION; this is the author's final, peer-reviewed manuscript. The published version may be accessed by following the link in the citation at the bottom of the page.

indicating that the people who were more controlled perceived greater temporal demand in the situation.

Table 7. Correlations between TLX and performance variables with conscientiousness scales.

\begin{tabular}{|l|l|l|l||}
\hline & Conscientiousness & Primary conscientiousness & Impulsivity (control) \\
\hline Security camera misses & -.17 & $-.18^{*}$ & -.11 \\
\hline \hline Puzzle completion & $.20^{*}$ & $.21^{*}$ & .10 \\
\hline Mental & .11 & .09 & .12 \\
\hline Physical & -.10 & -.10 & -.06 \\
\hline Temporal & .08 & .01 & $.18^{*}$ \\
\hline Performance & .16 & $.18^{*}$ & .07 \\
\hline Effort & .01 & .03 & -.00 \\
\hline Frustration & .03 & .01 & .03 \\
\hline
\end{tabular}

The multiple regression models for the four measures were re-analysed. The results for total misses in the vigilance task were a bit stronger when primary conscientiousness replaced the global construct $\left(R=.41, R^{2}=.16\right.$, adj. $\left.R^{2}=.14, F(3,124)=8.13, p<.001\right)$, but otherwise did not change dramatically. The results appear in Table 8 . The results for puzzle completion and performance demands did not change and are thus not reported further.

Table 8. Re-analysis of multiple regression models with primary conscientiousness and impulsivity as independent variables.

\begin{tabular}{|l|l|l||}
\hline Independent & \multicolumn{1}{|c|}{$\boldsymbol{1}$} \\
\hline Dependent: total security camera misses & \multicolumn{1}{c|}{$t$} \\
\hline Working in pairs & -.287 & $-3.467^{* * *}$ \\
\hline Work ethic & .217 & $2.594^{*}$ \\
\hline Primary conscientiousness & -.182 & $-2.164^{*}$ \\
\hline Dependent: TLX temporal demands & .286 & $3.529^{* * *}$ \\
\hline Working in pairs & .233 & $2.886^{* *}$ \\
\hline Anxiety & .422 & $3.724^{* * *}$ \\
\hline Impulsivity (control) & -.362 & $-2.981^{* *}$ \\
\hline Primary conscientiousness & .216 & $2.483^{*}$ \\
\hline Emotional intelligence & \\
\hline
\end{tabular}

However, the new results for temporal demands were interesting. Both primary conscientiousness and impulsivity entered the stepwise solution. However, the beta weights were in opposite directions such that people who perceived greater temporal demands were more controlled and scored lower on the primary conscientiousness 
subscale. The latter was functioning as a suppressor variable because it did not show a significant bivariate correlation with the criterion. In addition, EI entered the model on the last step; those with higher EI scores perceived greater temporal demand. The revised model for temporal demands was more accurate overall, accounting for an additional 11\% of the criterion variance $\left(R=.47, R^{2}=.22\right.$, adj. $\left.R^{2}=.19, F(5,122)=6.91, p<.001\right)$.

\subsection{Interaction effects}

No interaction effect was found for anxiety and working in pairs with miss errors on the security camera $\left(R=.30, R^{2}=.09\right.$, adj. $\left.R^{2}=.07, F(3,135)=4.58, p<.01\right)$, puzzle completion $\left(R=.541, R^{2}=.29\right.$, adj. $\left.R^{2}=.28, F(3,134)=18.48, p<.001\right)$, mental demand $\left(R=.13, R^{2}=.02\right.$, adj. $\left.R^{2}=.00, F(3,135)=0.74, \mathrm{NS}\right)$, physical demand $\left(R=.08, R^{2}=.01\right.$, adj. $\left.R^{2}=.00, F(3,135)=0.264, \mathrm{NS}\right)$, temporal demand $\left(R=.32, R^{2}=.10\right.$, adj. $R^{2}=.08, F(3$, $135)=4.97, p<.01)$, performance demand $\left(R=.28, R^{2}=.08\right.$, adj. $R^{2}=.06, F(3,135)=$ $3.08, p<.05)$, or frustration $\left(R=.24, R^{2}=.06\right.$, adj. $\left.R^{2}=.04, F(3,135)=2.73, p<.05\right)$. However, there was a small effect for effort demand $(p=.051)$ such that people scoring higher in anxiety perceived greater effort demands, but less so if they worked in pairs. The degree of fit for this three-variable model $\left(R=.23, R^{2}=.05\right.$, adj. $R^{2}=.03, F(3,135)=2.40$, $p<.07)$ was not as high as the two-variable model for EI plus the experimental condition where the camera frames increased or decreased speed $(R=.32)$ as reported in Section 3.1. Regression weights for the analyses of anxiety interaction effects appear in Table 9.

Table 9. Interaction effects for anxiety and working in pairs.

\begin{tabular}{|l||l|l|l|l||l|l||}
\hline \multicolumn{1}{|c|}{} & \multicolumn{2}{c|}{ Anxiety } & \multicolumn{2}{c|}{ Singles/pairs } & \multicolumn{2}{c||}{ Interaction } \\
\hline \hline Criterion & \multicolumn{1}{|c|}{$\boldsymbol{\beta}$} & $\boldsymbol{t}$ & $\boldsymbol{\beta}$ & \multicolumn{1}{c|}{$\boldsymbol{t}$} & \multicolumn{1}{c|}{$\boldsymbol{\beta}$} \\
\hline Vigilance misses & 0.06 & 0.50 & -0.20 & $-3.65^{* * *}$ & -0.07 & -0.58 \\
\hline Puzzle completion & -0.15 & -1.41 & 0.53 & $7.42^{* * *}$ & 0.16 & 1.42 \\
\hline TLX mental & 0.05 & 0.35 & 0.03 & 0.40 & 0.08 & 0.64 \\
\hline TLX physical & 0.08 & 0.58 & -0.01 & -0.16 & 0.00 & -0.01 \\
\hline TLX temporal & 0.27 & $2.13^{*}$ & 0.25 & $3.09^{* *}$ & -0.12 & -0.95 \\
\hline TLX performance & 0.03 & 0.26 & 0.28 & $3.36^{* * *}$ & -0.00 & -0.01 \\
\hline TLX effort & 0.34 & $2.63^{* *}$ & 0.05 & 0.58 & -0.25 & $-1.97 . a$ \\
\hline TLX frustration & 0.129 & 1.01 & 0.06 & 0.75 & 0.12 & 0.92 \\
\hline
\end{tabular}

No interaction effects were found between EI and working in pairs with miss errors on the security camera $\left(R=.33, R^{2}=.11\right.$, adj. $\left.R^{2}=.09, F(3,131)=5.50, p<.01\right)$, puzzle completion $\left(R=.56, R^{2}=.31\right.$, adj. $\left.R^{2}=.30, F(3,130)=19.82, p<.001\right)$, mental demands $\left(R=.18, R^{2}=.03\right.$, adj. $\left.R^{2}=.01, F(3,131)=1.47, \mathrm{NS}\right)$, physical demands $\left(R=.14, R^{2}=.02\right.$,

Theoretical Issues in Ergonomics Science, Vol. 16, No. 1 (2015): pg. 20-52. DOI. This article is (c) Taylor \& Francis and permission has been granted for this version to appear in e-Publications@Marquette. Taylor \& Francis does not grant permission for this article to be further copied/distributed or hosted elsewhere without the express permission from Taylor \& Francis. 
adj. $\left.R^{2}=.00, F(3,131)=0.82, \mathrm{NS}\right)$, or performance demands $\left(R=.41, R^{2}=.16\right.$, adj. $R^{2}$ $=.14, F(3,131)=8.59, p<.001)$. However, interaction effects were found for temporal demand, effort demand, and frustration. Regression weights for the EI interaction analyses appear in Table 10.

Table 10. Interaction effects for emotional intelligence and working in pairs.

\begin{tabular}{|c|c|c|c|c|c|c|}
\hline & \multicolumn{2}{|c|}{ Emotional intelligence } & \multicolumn{2}{|c|}{ Singles/pairs } & \multicolumn{2}{|c|}{ Interaction } \\
\hline Criterion & $\beta$ & $t$ & $\beta$ & $t$ & $\beta$ & $t$ \\
\hline Vigilance misses & 0.31 & 0.96 & 0.52 & 0.55 & -0.89 & -0.90 \\
\hline Puzzle completion & 0.30 & 1.05 & 0.90 & 1.09 & -0.39 & -0.45 \\
\hline TLX mental & -0.39 & -1.15 & -1.46 & -1.48 & 1.58 & 1.54 \\
\hline TLX physical & -0.48 & -1.42 & -1.53 & -1.54 & 1.58 & 1.52 \\
\hline TLX temporal & -0.62 & $-1.90 \cdot a$ & -1.97 & $-2.09^{*}$ & 2.33 & $2.36^{*}$ \\
\hline TLX performance & 0.42 & 1.34 & 0.72 & 0.78 & -0.44 & 0.46 \\
\hline TLX effort & -0.62 & $-1.91^{\mathrm{a}}$ & -2.50 & $-2.64^{* *}$ & 2.67 & $2.70^{* *}$ \\
\hline TLX frustration & -0.61 & $-1.79 . \mathrm{a}$ & -1.76 & -1.78 a & 1.89 & $1.83 \cdot \mathrm{a}$ \\
\hline
\end{tabular}

The results for the main effects for temporal demand showed that people who scored higher in EI experienced less temporal demand as did those who worked in pairs. Those who scored higher in EI and worked in pairs, however, experienced a greater temporal demand. The accuracy of this three-variable model $\left(R=.34, R^{2}=.11\right.$, adj. $R^{2}$ $=.09, F(3,131)=5.52, p<.001)$ was equivalent to the two-variable model reported containing anxiety plus working in pairs $(R=.33)$ reported in Section 3.1. A graph of the relationships that was generated from the unstandardised regression weights is shown in Figure 4. It is noteworthy that twice as many people in the study worked in pairs as worked alone.

Figure 4. The effects of the interaction between EI and working in pairs on temporal demand generated from unstandardised regression weights.

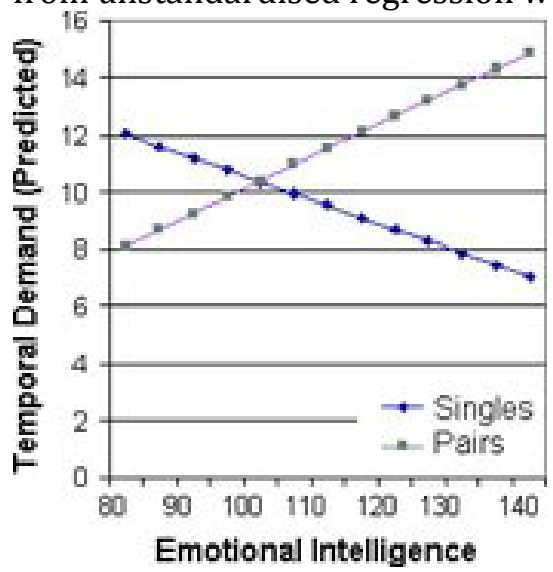

Theoretical Issues in Ergonomics Science, Vol. 16, No. 1 (2015): pg. 20-52. DOI. This article is (C) Taylor \& Francis and permission has been granted for this version to appear in e-Publications@Marquette. Taylor \& Francis does not grant permission for this article to be further copied/distributed or hosted elsewhere without the express permission from Taylor \& Francis. 
The main effects and interaction effect for effort demand showed a similar pattern of regression weights. The accuracy of this three-variable model $\left(R=.32, R^{2}=.10\right.$, adj. $R^{2}$ $=.08, F(3,131)=5.05, p<.01)$ was again equivalent to the two-variable model containing EI and task speed presented first $\left(R^{2}=.32\right)$. A graph of the relationships that was generated from the unstandardised regression weights is shown in Figure 5; working in pairs was apparently more demanding than working alone.

Figure 5. The effects of the interaction between EI and working in pairs on effort demand generated from unstandardised regression weights.

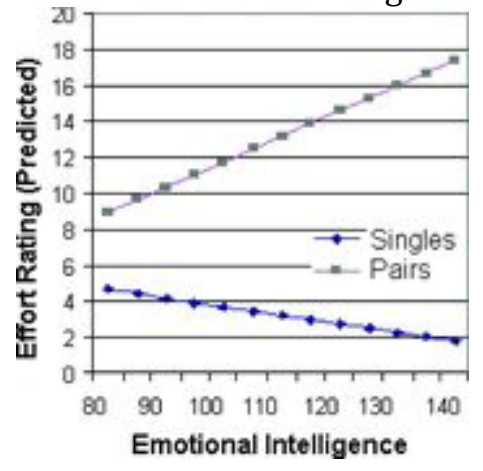

The main effects and interaction for frustration showed the same pattern that was found for temporal demand and effort demand. The accuracy of this model $\left(R=.16, R^{2}\right.$ $=.03$, adj. $\left.R^{2}=.00, F(3,131)=1.20, \mathrm{NS}\right)$ was not as high as the prediction from anxiety alone.

\section{Discussion}

Several important points were learned pertaining to the TLX subjective ratings of workload, the four principal constructs, and the effect of working alone or in pairs. Each is discussed in turn below and followed by suggestions for future research on individual differences and cognitive workload.

\subsection{TLX}

All TLX scales except physical demands were affected by individual differences in either anxiety or EI. The two constructs work together psychologically such that anxiety predisposes the individual to higher levels of arousal to a given stimulus or situation. Persons scoring higher in EI are more likely to recognise the effect and should engage some internal coping strategy to get arousal under control. Load is a source of stress; recognising

Theoretical Issues in Ergonomics Science, Vol. 16, No. 1 (2015): pg. 20-52. DOI. This article is @ Taylor \& Francis and permission has been granted for this version to appear in e-Publications@Marquette. Taylor \& Francis does not grant permission for this article to be further copied/distributed or hosted elsewhere without the express permission from Taylor \& Francis. 
the presence of stress is the first step toward nullifying its negative effect on one's immediate work activities if not also for longer term well-being.

Physical demands from the experimental tasks were actually very low. Most participants said so on the TLX rating, but a few gave some highly unrealistic ratings. The unrealistic ratings could have been produced by lack of any anchors other than 'very low' to 'very high' at the opposite poles. They could also have been examples of rating errors that are commonly known in person perception and performance evaluation, which are halo, central tendency, and leniency or severity error (Guion 1998). However, it does not appear that these types of error have been explored in ratings of task workload. Leniency or severity error seemed to be the most apparent of the three types of rating errors in the case of physical demands. Leniency or severity error occurs when a rater rates all people, tasks, or objects too far to the high or low end of the scale. Although it is not easily discernible from halo error in the present situation, some participants did indeed provide unrealistically high ratings for physical demands, which were in turn correlated with ratings of mental demand, temporal demand, and frustration. The findings thus indicate the need for anchors, although anchors might be difficult to generalise from one application to another. Fortunately, the impact of leniency or severity error can be negated in studies that compare tasks or system designs. By matching ratings of multiple objects by one person, only the differences between the ratings register as the experimental effect.

The study provided some opportunity to explore the connection between the TLX and task performance in light of the dissociation reported in earlier studies. As it turned out, TLX scales were not associated with performance on the vigilance task. However, two scales, performance pressure and physical demands, were correlated with puzzle completion. The effect for physical demands was actually a suppressor effect that corrected for leniency or severity error.

\subsection{Speed order effects}

Some participants started with the slower condition and worked up to the faster condition, and others started with the faster condition and slowed down. The speed order condition only affected one TLX scale - perceived effort. Perceived effort was rated lower by those who started in the faster condition and then slowed down. Cox-Fuenzalida et al. (2004) explained a similar result as speeding up requiring a greater adaptive response, which challenged people higher in anxiety more so than others. Szalma and Taylor (2011) appeared to arrive at a similar conclusion regarding the relationship between stress, coping, and anxiety.

Theoretical Issues in Ergonomics Science, Vol. 16, No. 1 (2015): pg. 20-52. DOI. This article is (C) Taylor \& Francis and permission has been granted for this version to appear in e-Publications@Marquette. Taylor \& Francis does not grant permission for this article to be further copied/distributed or hosted elsewhere without the express permission from Taylor \& Francis. 
The study by Szalma and Teo (2012), however, would suggest that the critical points for producing adaptive responses to a workload that is too slow and one that is too fast are asymmetrical; critical points in both directions would be found if the conditions were fast enough or slow enough. At the same time there are dissociations between perceived load and performance and between speed and accuracy that need to be studied further.

However, an alternative explanation for the speed order effect obtained here is that the participants were experiencing a recency effect. Fast-first would mean that the slower speed was more readily remembered when the ratings were given. Similarly slow-first would mean that the faster speed was more often remembered. The ambiguity between the two interpretations of the results would need to be investigated further.

\subsection{Working in pairs}

The experimental condition involving two participants working together on the two tasks was expected to lower the perceived workload under the thinking that 'many hands make light the work.' However, that is apparently not what happened. Instead, higher ratings of performance pressure and temporal demands were associated with working in pairs. Ratings of mental workload, perceived effort, and frustration were generally not affected by the manipulation, but there was some apparent impact of working in pairs on effort and frustration when interactions between EI and working in pairs were considered. Apprehension about performance evaluations and social facilitation could have influenced the results of the present study, and further research is needed to examine the possibilities.

The best means for determining a group workload from individual ratings is currently an unresolved issue (Funke et al. 2012). The present findings suggest that a complication exists that needs to be resolved in future research on group workloads. Factors such as the mere presence of other people and apprehension about performance evaluation or social facilitation for getting the job done could influence physiological, subjective, and behavioural indices of group workload as they might have done in the present study. For the time being we learned that people higher in EI experience greater temporal demand, effort demand, and frustration when working with a co-worker. The specific nature of interactions that produces the effect is not known, but possibilities include the added effort to synchronise work performance with the co-worker (coordination cost), to counteract perceived social loafing, or to adjust to an individual that is perceived as dominating.

Theoretical Issues in Ergonomics Science, Vol. 16, No. 1 (2015): pg. 20-52. DOI. This article is (C) Taylor \& Francis and permission has been granted for this version to appear in e-Publications@Marquette. Taylor \& Francis does not grant permission for this article to be further copied/distributed or hosted elsewhere without the express permission from Taylor \& Francis. 
It is also possible that the structure of the tasks could be an overriding determinant of how individual workloads compile into group workloads. Tasks that allow a greater number of degrees of freedom for switching off tasks among individuals might afford greater elasticity in response to workload changes. Bottlenecks within the group's workflow, however, could be a source of rigidity. The tasks performed in the present study were not susceptible to either influence because the participants were instructed that they were both responsible for both tasks, and they worked in parallel rather than in a serial process.

\subsection{Psychosocial variables}

Four variables were hypothesised to contribute to the subjective ratings of workload and performance. Anxiety displayed a connection to ratings of temporal demands and frustration such that anxious people gave higher ratings on both TLX scales. The latter connection was consistent with Cox-Fuenzalida et al. (2004) and Rose et al. (2002). Anxious people thus seemed more sensitive to time pressure. However, their anxiety or experience of frustration did not appear to impact their task performance, in contrast to Cox-Fuenzalida et al. (2004). The anxiety-performance connection, or apparent lack of the same, is consistent with the previous research showing that anxiety can have both positive and negative effects on performance; so the net effect observed here was no effect (Ein-Dor et al. 2010). The high-anxiety participants could have been exerting compensatory efforts as Matthews et al. (2000) and Szalma (2008) might suggest, or the dual-task situation provided enough mental workload to negate the effects of anxiety by not allowing mental time for non-task ruminations, as Vytal et al. (2012).

EI displayed an effect on ratings of mental demand, performance pressure, and effort, where participants scoring higher on EI gave higher ratings on all three TLX scales. They seemed to be more sensitive to the situational demands and possibly their own responses; this interpretation would be consistent with the basic definition of EI (Mayer and Salovey 1997). EI had a direct positive relationship with puzzle completion, but not the vigilance task. The reason why EI would impact on one task and not the other is not forthcoming from the data, but one might speculate that tasks that are more engaging, or at least higher load, would trigger the EI characteristic more so than less engaging or lower load tasks, because more mental effort would go into self-regulation of emotions such as the experience of stress and boredom. An alternative speculation that is perhaps more germane to the dual task is that the participants quickly figured out that they would be very bored with watching security screens without interruption and occupied themselves

Theoretical Issues in Ergonomics Science, Vol. 16, No. 1 (2015): pg. 20-52. DOI. This article is (C) Taylor \& Francis and permission has been granted for this version to appear in e-Publications@Marquette. Taylor \& Francis does not grant permission for this article to be further copied/distributed or hosted elsewhere without the express permission from Taylor \& Francis. 
effectively with the other task that they were assigned. At the same time they did not allow their personal reactions to interfere with the vigilance tasks.

Conscientiousness was unrelated to ratings of subjective workload. It played a small role in the performance of the vigilance task where people scoring higher in conscientiousness missed fewer targets. This finding was consistent with Rose et al. (2002). In light of the nature of the construct, which featured attention to details, and its long-run history as a predictor of work performance in many contexts, this result was not surprising. Conscientiousness had a small bivariate correlation with puzzle completion, but this effect was redundant with other predictors of puzzle completion in the multiple regression model.

The separation of conscientiousness into two scales produced some nominal effects for vigilance, puzzle completion, and performance demands. However, the separation made a marked improvement in the explanation of temporal demands. The participants who perceived greater demands were more controlled on the one hand, but less attentive to details on the other. Those who perceived lighter temporal demand were more attentive to detail but more impulsive.

PWE was also unrelated to the subjective measures of workload except frustration. The multiple regression analysis, however, showed that its effect on frustration was redundant with a larger effect associated with anxiety. Although it was correlated with both performance criteria in the multiple regression analyses, the effect was the opposite of what would be expected based on the nature of the construct. Participants who scored higher in PWE actually accomplished less of the puzzle and made more errors on the vigilance task. An explanation for these inverse relationships was not forthcoming from the data, but one might speculate that (1) it was actually capturing a tendency to overcompensate for mediocre diligence or attention focus, (2) it reflected the independence aspect of PWE, (3) the construct does not have the same relevance it might have had 30-40 years ago. Explanation (1) could be the result of the correlation found between anxiety and PWE. According to Furnham (1990), Buchholz's (1977) scale and other versions of PWE that he studied were consistent with the PWE construct. The internal consistency of measure used in this study was low and might be related to simply having too few items or not enough variability in the responses from the participants. Longer scales might be more helpful in future research on PWE in ergonomics.

Meanwhile, one impetus for studying PWE in the 1970s was the folk observation that PWE was no longer the dominant belief system about work. Perhaps PWE has become

Theoretical Issues in Ergonomics Science, Vol. 16, No. 1 (2015): pg. 20-52. DOI. This article is (C) Taylor \& Francis and permission has been granted for this version to appear in e-Publications@Marquette. Taylor \& Francis does not grant permission for this article to be further copied/distributed or hosted elsewhere without the express permission from Taylor \& Francis. 
an acquired taste for many people in the twenty-first century. If one feature of the PWE is to find value in work even if it is boring or tedious and perform it better or longer (Greenberg 1977), it would follow that the self-regulation of emotion and behaviour that appears implicit in PWE would not have been learned. Further study of PWE could be of interest, although many of the concomitant issues would stray beyond the present concern for individual differences in cognitive workload and other aspects of system design, especially for products that are leisure oriented and not necessarily work oriented.

\section{Conclusions and future directions}

The results of the present study allowed for the following conclusions:

1. Subjective measures of cognitive workload are influenced by at least a few individual differences. The two more prominent ones were anxiety and EI.

2. Subjective ratings of cognitive workload, specifically the TLX scales, are subject to classic forms of rating bias, most notably leniency-severity error.

3. Of the six TLX scales, performance demands, which captures a characteristic of the individual rather than the task itself, was the scale most proximally related to performance on one of the tasks, but not the other.

4. Individuals who worked in pairs experienced greater temporal demand and performance pressure compared to those who performed the two tasks alone.

Some specific recommendations for future research that were suggested already can be re-aggregated with further ideas:

1. Researchers who intend to use TLX for evaluating system configurations should consider adding anchors to remove the equivalent of halo or leniency-severity errors in ratings. Alternatively, experimental designs should be adopted that could also negate the bias problem, such as designs that compare a set of within-person ratings given to a series of conditions. The drawback of that technique is that in some cases stopping the work process to give ratings could interrupt the cognitive flow that is taking place as working conditions are subtly changing. The rating activity could induce a task-switching cost.

2. The four psychosocial variables studied here should be revisited in other contexts where different task and stress demands are involved. The nexus of anxiety, EI, and frustration appears particularly promising, and those constructs should be explored further. The present study did not explore interactions among the constructs because doing so would involve a large number of two-, three-, and four-way interactions that could not plausibly produce a generalisable pattern. However, future studies could consider interactions among some possible combinations of variables. Within the non-linear dynamics context (cusp catastrophe) that

Theoretical Issues in Ergonomics Science, Vol. 16, No. 1 (2015): pg. 20-52. DOI. This article is (C) Taylor \& Francis and permission has been granted for this version to appear in e-Publications@Marquette. Taylor \& Francis does not grant permission for this article to be further copied/distributed or hosted elsewhere without the express permission from Taylor \& Francis. 
generated the elasticity-rigidity construct, the elasticity or rigidity variables do not actually interact with each other; they interact with initial performance levels, thus producing trajectories over time.

3. The schism between variables affecting workload perception and those affecting performance could be explored with a wider variety of data. More emphasis should be given to coping strategies that people might use to counter overload and underload conditions or motivational aspects of the work situation (e.g. Hancock 1996; Hancock and Warm 1989; Szalma 2008).

4. The processes by which individuals' subjective ratings are affected by group dynamics is a wide open area for study. Non-linear dynamical processes, particularly those linked to behavioural synchronisation, have been implicated on multiple occasions (Cooke et al. 2012; Funke et al. 2012; Stevens et al. 2013) and speak to the level of complexity that is probably involved in the individual-to-group process. As an example, there is probably some question as to whether the dyads in the present study were really teams or just nominal dyads. The participating individuals did not have a prior history of working together, but the instructions were given to encourage team efforts. The informal observations of their talk, or lack of the same, however, indicated that varying levels of coordinated task engagement and interpersonal cohesion were taking place.

5. The counter-intuitive connection between PWE and performance warrants further research. The independence trait or facet of PWE could be a viable candidate for further study as well.

6. The psychosocial variables that were explored in the present study were scouted for possible further connections to the principle of elasticity or resilience. In order to test elasticity explicitly, the mathematical models shown in Figure 1 and an analysis thereof would be required along with behavioural indicators of workload effects that are measured at two or more points in time. The two cusp catastrophe models proposed earlier (Guastello, Boeh, Shumaker et al. 2012; Guastello, Boeh, Schimmels et al. 2012; Guastello, Boeh et al. 2013) would also allow for the separation of workload and fatigue effects, which were potentially conflated in subjective scales the way they are usually used.

\section{Acknowledgements}

The authors wish to thank the anonymous reviewers for numerous insights and suggestions that are reflected in this article. The responsibility for anything presented here is, of course, ours. The authors also wish to thank Megan Fabisch, Hillary Gorin, Kirsten Poston and Kelsey Weinberger for their assistance with data collection.

\section{References}

Ackerman, P.L., ed. 2011. Cognitive Fatigue. Washington, DC: American Psychological Association.

Theoretical Issues in Ergonomics Science, Vol. 16, No. 1 (2015): pg. 20-52. DOI. This article is (C Taylor \& Francis and permission has been granted for this version to appear in e-Publications@Marquette. Taylor \& Francis does not grant permission for this article to be further copied/distributed or hosted elsewhere without the express permission from Taylor \& Francis. 
NOT THE PUBLISHED VERSION; this is the author's final, peer-reviewed manuscript. The published version may be accessed by following the link in the citation at the bottom of the page.

Alves, E.E., and C.M. Kelsey. 2010. “Combating Vigilance Decrement in a Single-Operator Radar Platform." Ergonomics in Design 18 (2): 6-9.

Amelang, M., and R. Steinmayr. 2006. "Is There a Validity Increment for Tests of Emotional Intelligence in Explaining the Variance of Performance Criteria?" Intelligence 34: 459-468.

Babyak, M.A. 2004. "What You See May Not Be What You Get: A Brief, Nontechnical Introduction to Overfitting in Regression-Type Models." Psychosomatic Methods 66: 411-421.

Baldwin, C.L. 2009. "Individual Differences in Navigational Strategy: Implications for Display Design." Theoretical Issues in Ergonomics Science 10: 443-458.

Bandura, A., and E.A. Locke. 2003. "Negative Self-Efficacy and Goal Effects Revisited." Journal of Applied Psychology 88: 87-99.

Barnes, C.M., J.R. Hollenbeck, D.T. Wagner, D.S. DeRue, J.D. Nahgang, and K.M. Schwind. 2008. "Harmful Help: The Costs of Backing-Up Behavior in Teams." Journal of Applied Psychology 90: 529-539.

Battiste, V., and M. Bortolussi. 1988. "Transport Pilot Workload: A Comparison of Two Subjective Techniques." Proceedings of the Human Factors Society Thirty-Second Annual Meeting, 150154. Santa Monica, CA: Human Factors Society.

Bond, C.F., Jr., and L.J. Titus. 1983. "Social Facilitation: A Meta-analysis of 241 Studies." Psychological Bulletin 94: 265-292.

Braarud, P.O. 2001. "Subjective Task Complexity and Subjective Workload: Criterion Validity for Complex Team Tasks." International Journal of Cognitive Ergonomics 5: 261-273.

Buchholz, R.A. 1977. "The Belief Structure of Managers Relative to Work Concepts Measured by a Factor Analytic Model.” Personnel Psychology30: 567-587.

Byers, J.C., A.C. Bittner, Jr., and S.G. Hill. 1989. "Traditional and Raw Task Load Index (TLX) Correlations: Are Paired Comparisons Necessary?" In Advances in Industrial Ergonomics and Safety, edited by A. Mital, 481-485. Washington, DC: Taylor and Francis.

Byers, J.C., A.C. Bittner, S.G. Hill, A.L. Zaklad, and R.E. Christ. 1988. "Workload Assessment of a Remotely Piloted Vehicle (RPV) System." Proceedings of the Human Factors Society Thirty-Second Annual Meeting, 1145-1149. Santa Monica, CA: Human Factors Society.

Byrne, Z.S., J. Stoner, K.R. Thompson, and W. Hichwarter. 2005. "The Interactive Effects of Conscientiousness, Work Effort, and Psychological Climate on Job Performance." Journal of Vocational Behavior 66: 326-338.

Cattell, H.E.P. 1994. "Development of the 16PF Fifth Edition.” In 16PF Fifth Edition: Technical Manual, edited by S.R. Conn and M.L. Rieke, 1-20. Champaign, IL: Institute for Personality and Ability Testing.

Cattell, H.E.P., and A.D. Mead. 2008. "The Sixteen Personality Factor Questionnaire (16PF)." In The Sage Handbook of Personality Theory and Assessment, 2: Personality Measurement and Testing, edited by G.J. Boyle, G. Matthew, and D.H. Sakofske, 135-159. Thousand Oaks, CA: Sage.

Cattell, R.B., H.W. Eber, and M.M. Tatsuoka. 1970. Handbook for the Sixteen Personality Factor Questionnaire. Champaign, IL: Institute for Personality and Ability Testing.

Cherniss, C. 2010. "Emotional Intelligence: Toward Clarification of a Concept." Industrial and Organizational Psychology 3: 110-126.

Cohen, J. 1990. “Things I've Learned (So Far).” American Psychologist45: 1304-1312.

Conn, S., and M.L. Rieke, eds. 1994. The 16PF Fifth Edition, Technical Manual. Champaign, IL: Institute for Personality and Ability Testing.

Theoretical Issues in Ergonomics Science, Vol. 16, No. 1 (2015): pg. 20-52. DOI. This article is @ Taylor \& Francis and permission has been granted for this version to appear in e-Publications@Marquette. Taylor \& Francis does not grant permission for this article to be further copied/distributed or hosted elsewhere without the express permission from Taylor \& Francis. 
NOT THE PUBLISHED VERSION; this is the author's final, peer-reviewed manuscript. The published version may be accessed by following the link in the citation at the bottom of the page.

Conrad, R. 1951. "Speed and Load Stress in a Sensorimotor Skill." British Journal of Industrial Medicine 8: $1-7$.

Cooke, N.J., P.G. Amazeen, J.C. Gorman, S.J. Guastello, A. Likens, and R. Stevens. 2012. "Modeling the Complex Dynamics of Teamwork from Team Cognition to Neurophysiology." Proceedings of the Human Factors and Ergonomics Society 56: 183-187.

Costa, P.T., and R.R. McCrae. 1992. "Four Ways Five Factors Are Basic." Personality and Individual Differences 13: 653-665.

Cox-Fuenzalida, L.-E., A. Angie, S. Holloway, and L. Sohl. 2006. "Extraversion and Task Performance: A Fresh Look Through the Workload History Lens." Journal of Research in Personality 40: 432439.

Cox-Fuenzalida, L.-E., R. Swickert, and J.B. Hittner. 2004. "Effects of Neuroticism and Workload History on Performance." Personality and Individual Differences 36: 447-456.

Darlington, R.B. 1990. Regression and Linear Models. New York: McGraw-Hill.

Dennis, A.R., and J.S. Valacich. 1993. "Computer Brainstorms: More Heads Are Better than One." Journal of Applied Psychology 78: 531-537.

Derkson, S., and H.J. Kelseman. 1992. "Backward, Forward and Stepwise Automated Subset Selection Algorithms: Frequency of Obtaining Authentic and Noise Variables." British Journal of Mathematical and Statistical Psychology 45: 265-282.

Dey. A., and D.D. Mann. 2010. "Sensitivity and Diagnosticity of NASA-TLX and Simplified SWAT to Assess the Mental Workload Associated with Operating an Agricultural Sprayer." Ergonomics 53: 848857.

Dickinson, J., W.D. Byblow, and L.A. Ryan. 1993. "Order Effects and the Weighing Process of Workload Assessment." Applied Ergonomics 24: 357-361.

Douglas, C., D.D. Frink, and G.R. Ferris. 2004. "Emotional Intelligence as a Moderator of the Relationship Between Conscientiousness and Performance." Journal of Leadership \& Organizational Studies 10: 2-3.

Drury, C.G., K. Holness, K.M. Ghysin, and B.D. Green. 2009. “Using Individual Differences to Build a Common Core Dataset for Aviation Security Studies." Theoretical Issues in Ergonomics Science 10: 459-480.

Dudley, N.M., K.A. Orvis, J.E. Lebiecki, and J.M. Cortina. 2006. "A Meta-analytic Investigation of Conscientiousness in the Prediction of Job Performance: Examining the Intercorrelations and the Incremental Validity of Narrow Traits." Journal of Applied Psychology 91: 40-57.

Ein-Dor, T., M. Mikulincer, G. Doron, and P.R. Shaver. 2010. "The Attachment Paradox: How Can So Many of Us (the Insecure Ones) Have No Adaptive Advantages." Perspectives on Psychological Science 5: 123-141.

Evans, M.G. 1991. “The Problem of Analyzing Multiplicative Composites.” American Psychologist 46: 615.

Eysenck, M.W. 1997. Anxiety and Cognition: A Unified Theory. New York: Psychology Press/Taylor and Francis.

Eysenck, M.W. 2010. “Attentional Control of Anxiety: Recent Developments.” In Handbook of Individual Differences in Cognition: Attention, Memory, and Executive Control, edited by A. Gruszka, G. Matthews, and B. Szymura, 175-204. New York: Springer.

Theoretical Issues in Ergonomics Science, Vol. 16, No. 1 (2015): pg. 20-52. DOI. This article is @ Taylor \& Francis and permission has been granted for this version to appear in e-Publications@Marquette. Taylor \& Francis does not grant permission for this article to be further copied/distributed or hosted elsewhere without the express permission from Taylor \& Francis. 
NOT THE PUBLISHED VERSION; this is the author's final, peer-reviewed manuscript. The published version may be accessed by following the link in the citation at the bottom of the page.

Funke, G.J., B.A. Knott, E. Salas, D. Pavlas, and A.J. Strang. 2012. "Conceptualization and Measurement of Team Workload: A Critical Need." Human Factors 54: 36-51.

Furnham, A. 1990. "A Content, Correlational, and Factor Analytic Study of Seven Questionnaire Measures of the Protestant Work Ethic." Human Relations 43: 383-399.

Goldberg, L. 2011. “International Personality Item Pool.” Accessed September 30, 2011. http://ipip/ori.org.

Gordon, J.E. 1978. Structures, or Why Things Don't Fall Down. New York: Penguin.

Green, S.B. 1991. "How Many Subjects Does It Take to Do a Regression?" Multivariate Behavioral Research 26: 499-510.

Greenberg, J. 1977. "The Protestant Work Ethic and Reactions to Negative Performance Evaluations on a Laboratory Task." Journal of Applied Psychology 62: 682-690.

Guastello, A.D., S.J. Guastello, and D.D. Guastello. 2013. "Personality Trait Theory and Multitasking Performance: Implications for Ergonomic Design.” Theoretical Issues in Ergonomics Science. doi: 10.1080/1463922X.2012.762063.

Guastello, S.J. 1985. "Euler Buckling in a Wheelbarrow Obstacle Course: A Catastrophe with Complex Lag." Behavioral Science 30: 204-212.

Guastello, S.J. 1995. Chaos, Catastrophe, and Human Affairs: Applications of Nonlinear Dynamics to Work, Organizations, and Social Evolution. Hillsdale, NJ: Lawrence Erlbaum Associates.

Guastello, S.J. 2003. "Nonlinear Dynamics, Complex Systems, and Occupational Accidents." Human Factors in Manufacturing 13: 293-304.

Guastello, S.J. 2010. "Nonlinear Dynamics of Team Performance and Adaptability in Emergency Response." Human Factors 52: 162-172.

Guastello, S.J. 2011. "Discontinuities: SETAR and Catastrophe Models with Polynomial Regression." In Nonlinear Dynamical Systems Analysis for the Behavioral Sciences Using Real Data, edited by S.J. Guastello and R.A.M. Gregson, 251-280. Boca Raton, FL: CRC Press/Taylor and Francis.

Guastello, S.J. 2013. "Catastrophe Theory and Its Applications to I/O Psychology." In Frontiers of Methodology in Organizational Research, edited by J.M. Cortina and R. Landis, 29-61. New York: Routledge.

Guastello, S.J., H. Boeh, H. Gorin, S. Huschen, N.E. Peters, M. Fabisch, and K. Poston. 2013. "Cusp Catastrophe Models for Cognitive Workload and Fatigue: A Comparison of Seven Task Types." Nonlinear Dynamics, Psychology, and Life Sciences 17: 23-48.

Guastello, S.J., H. Boeh, M. Schimmels, H. Gorin, S. Huschen, E. Davis, N.E. Peters, M. Fabisch, and K. Poston. 2012. "Cusp Catastrophe Models for Cognitive Workload and Fatigue in a Verbally Cued Pictorial Memory Task." Human Factors 54: 811-825.

Guastello, S.J., H. Boeh, C. Shumaker, and M. Schimmels. 2012. "Catastrophe Models for Cognitive Workload and Fatigue." Theoretical Issues in Ergonomic Sciences 13: 586-602.

Guastello, S.J., H. Gorin, Huschen, S.N.E. Peters, M. Fabisch, and K. Poston. 2012. "New Paradigm for Task Switching Strategies While Performing Multiple Tasks: Entropy and Symbolic Dynamics Analysis of Voluntary Patterns." Nonlinear Dynamics, Psychology, and Life Sciences 16: 471-497.

Guastello, S.J., and M. Lynn. Forthcoming. "Catastrophe Model of the Accident Process, Safety Climate, and Anxiety." Nonlinear Dynamics, Psychology, and Life Sciences.

Theoretical Issues in Ergonomics Science, Vol. 16, No. 1 (2015): pg. 20-52. DOI. This article is (C) Taylor \& Francis and permission has been granted for this version to appear in e-Publications@Marquette. Taylor \& Francis does not grant permission for this article to be further copied/distributed or hosted elsewhere without the express permission from Taylor \& Francis. 
NOT THE PUBLISHED VERSION; this is the author's final, peer-reviewed manuscript. The published version may be accessed by following the link in the citation at the bottom of the page.

Guastello, S.J., M. Malon, P. Timm, K. Weinberger, H. Gorin, M. Fabisch, and K. Poston. 2013. "Cusp Catastrophe Models for Cognitive Workload and Fatigue in a Vigilance Dual Task." Human Factors. doi:10.1177/001872081350877.

Guastello, S.J., and D.W. McGee. 1987. "Mathematical Modeling of Fatigue in Physically Demanding Jobs." Journal of Mathematical Psychology31: 248-269.

Guastello, S.J., A. Shircel, D. Poggi, M. Malon, P. Timm, K. Weinberger, K. Reiter, and M. Fabisch. 2013. "Cusp Catastrophe Models for Cognitive Workload and Fatigue: A New Paradigm for Studying Biases in Financial Decision Making." Paper presented at the 23rd Annual International Conference of the Society for Chaos Theory in Psychology \& Life Sciences, Portland, OR.

Guion, R.M. 1998. Assessment, Measurement, and Prediction for Personnel Decision. Mahwah, NJ: Lawrence Erlbaum Associates.

Hancock, P.A. 1996. "Effects of Control Order, Augmented Feedback, Input Device and Practice on Tracking Performance and Perceived Workload." Ergonomics 39: 1146-1162.

Hancock, P.A. 2013. "In Search of Vigilance: The Problem of Iatrogenically Created Psychological Phenomena." American Psychologist 68: 97-109.

Hancock, P.A., and P.A. Desmond, eds. 2001. Stress, Workload, and Fatigue. Mahwah, NJ: Lawrence Erlbaum Associates.

Hancock, P.A., G.M. Hancock, and J.S. Warm. 2009. "Individuation: The N = 1 Revolution." Theoretical Issues in Ergonomics Science 10: 481-488.

Hancock, P.A., and J.S. Warm. 1989. “A Dynamic Model of Stress and Sustained Attention.” Human Factors 31: 519-537.

Hart, S.G. 1986. "Theory and Measurement of Human Workload.” In Human Productivity Enhancement: Training and Human Factors in Systems Design, edited by J. Zeidner, 396-456. New York: Praeger.

Hart, S.G. 2008. "NASA-Task Load Index (NASA-TLX) 20 Years Later." Proceedings of the Human Factors and Ergonomics Society 50: 904-908.

Hart, S.G., and L.E. Staveland. 1988. "Development of the NASA Task Load Index (TLX): Results of Experimental and Theoretical Research." In Human Workload, edited by P.A. Hancoke and N. Meshkati, 138-183. Amsterdam: North-Holland.

Hertel, G., N.L. Kerr, and L.A. Messé. 2000. "Motivation Gains in Performance Groups: Paradigmatic and Theoretical Developments on the Köhler Effect." Journal of Personality and Social Psychology 79: 580-601.

Joseph, D.L., and D.A. Newman. 2010. "Emotional Intelligence: An Integrative Meta-analysis and Cascading Model." Journal of Applied Psychology 95: 54-78.

Kane, M.J., and R.W. Engle. 2002. "The Role of Prefrontal Cortex in Working-Memory Capacity, Executive Attention, and General Fluid Intelligence: An Individual-Differences Perspective." Psychonomic Bulletin \& Review 9: 617-671.

Kantowitz, B., and D. Sorkin. 1983. Human Factors: Understanding People-System Relationships. New York: Wiley.

Karwowski, W. 2000. "Symvatology: The Science of an Artifact-Human Compatibility. Theoretical Issues in Ergonomics Science 1: 76-91.

Leary, M.R. 1990. “Anxiety, Cognition, and Behavior: In Search of a Broader Perspective." Journal of Social Behavior and Personality 5: 39-44.

Theoretical Issues in Ergonomics Science, Vol. 16, No. 1 (2015): pg. 20-52. DOI. This article is @ Taylor \& Francis and permission has been granted for this version to appear in e-Publications@Marquette. Taylor \& Francis does not grant permission for this article to be further copied/distributed or hosted elsewhere without the express permission from Taylor \& Francis. 
NOT THE PUBLISHED VERSION; this is the author's final, peer-reviewed manuscript. The published version may be accessed by following the link in the citation at the bottom of the page.

Leary, M.R. 2012. Introduction to Behavioral Research Methods. 6th ed. Boston, MA: Pearson.

Leary, M.R., and R.M. Kowalski. 1995. Social Anxiety. New York: Guilford Press.

Logie, R.H. 2011. "The Functional Organization and Capacity Limits of Working Memory." Current Directions in Psychological Science 20: 240-245.

MacLean, M.H., and K.M. Arnell. 2010. "Personality Predicts Temporal Attention Costs in the Attentional Blink Paradigm.” Psychonomic Bulletin \& Review 17: 556-562.

Matthews, G., and S.E. Campbell. 2009. "Sustained Performance Under Overload: Personality and Individual Differences in Stress and Coping." Theoretical Issues in Ergonomics Science 10: 417443.

Matthews, G., D.R. Davies, S.J. Westerman, and R.B. Stammers. 2000. Human Performance: Cognition, Stress, and Individual Differences. London: Psychology Press.

Matthews, G., P.A. Desmond, C. Neubauer, and P.A. Hancock, eds. 2012. The Handbook of Operator Fatigue. Aldershot: Ashgate.

Mayer, J.D. 2001. "A Field Guide to Emotional Intelligence." In Emotional Intelligence in Everyday Life: A Scientific Inquiry, edited by J. Ciarrochi, J.P. Forgas, and J.D. Mayer, 3-24. Philadelphia, PA: Taylor and Francis.

Mayer, J.D., and P. Salovey. 1997. "What Is Emotional Intelligence?” In Emotional Development and Emotional Intelligence: Educational Implications, edited by P. Salovey and D. Sluyter, 3-34. New York: Basic Books.

Meyer, R.D., R.S. Dalal, and S. Bonaccio. 2009. "A Meta-analytic Investigation into the Moderating Effects of Situational Strength on the Conscientiousness-Performance relationship." Journal of Organizational Behavior 30: 1077-1102.

Moroney, W.F., D. Biers, and T.F. Eggemeier. 1995. "Some Measurement and Methodological Considerations in the Application of Subjective Workload Measurement Techniques." The International Journal of Aviation Psychology 5: 87-106.

Murphy, L.R., D. DuBois, and J.J. Hurrell. 1986. "Accident Reduction Through Stress Management.” Journal of Business and Psychology 1: 5-18.

NASA Ames Research Center. n.d. NASA Task Load Index (TLX) 1.0: Paper and Pencil Package. Moffett Field, CA: NASA Ames Research Center. Accessed September 30, 2011. http://humansystems.arc.nasa.gov/groups/TLX/paperpencil.html.

Nataupsky, M., and T.S. Abbott. 1987. "Comparison of Workload Measures on Computer Generated Primary Flight Displays." Proceedings of the Human Factors Society Thirty-First Annual Meeting, 548-552. Santa Monica, CA: Human Factors Society.

Noyes, J.M., and D.P.J. Bruneau. 2007. “A Self-analysis of the NASA-TLX Workload Measure.” Ergonomics 50: 514-519.

O’Boyle, E.H., Jr., R.H. Humphrey, H.M. Pollack, T.H. Hawyer, and P.A. Story. 2011. "The Relationship Between Emotional Intelligence and Job Performance: A Meta-analysis." Journal of Organizational Behavior 32: 788-818.

Oron-Gilad, T., J.L. Szalma, S.C. Stafford, and P.A. Hancock. 2008. "The Workload and Performance Relationship in the Real World: A Study of Police Officers in a Field Shooting Exercise." International Journal of Occupational Safety and Ergonomics 14: 119-131.

Pincus, D., and A. Metten. 2010. "Nonlinear Dynamics in Biopsychosocial Resilience." Nonlinear Dynamics, Psychology, and Life Sciences 14: 353-380.

Theoretical Issues in Ergonomics Science, Vol. 16, No. 1 (2015): pg. 20-52. DOI. This article is @ Taylor \& Francis and permission has been granted for this version to appear in e-Publications@Marquette. Taylor \& Francis does not grant permission for this article to be further copied/distributed or hosted elsewhere without the express permission from Taylor \& Francis. 
NOT THE PUBLISHED VERSION; this is the author's final, peer-reviewed manuscript. The published version may be accessed by following the link in the citation at the bottom of the page.

Quick, J.C., L.R. Murphy, and J.J. Hurrell, Jr., eds. 1992. Stress and Well-Being at Work. Washington, DC: American Psychological Association.

Ralph, J., W.D. Gray, and M.J. Schoelles. 2010. "Squeezing the Balloon: Analyzing the Unpredictable Effects of Cognitive Workload." Proceedings of the Human Factors and Ergonomics Society 54: 299-303.

Rose, C.L., L.B. Murphy, L. Byard, and K. Nikzad. 2002. "The Role of the Big Five Personality Factors in Vigilance Performance and Workload." European Journal of Personality 16: 185-200.

Salovey, P., and J.D. Mayer. 1990. “Emotional Intelligence.” Imagination, Cognition, and Personality 9: 185-211.

Schutte, N.S., J.M. Malouf, L.E. Hall, D.J. Haggerty, J.T. Cooper, C.J. Golden, and L. Dornheirn. 1998. "Development and Validation of a Measure of Emotional Intelligence." Personality and Individual Differences 25: 167-177.

Shepperd, J.A. 1993. "Productivity Loss in Performance Groups: A Motivation Study.” Psychological Bulletin 113: 67-81.

Shively, R., V. Battiste, J. Matsumoto, D. Pepiton, M. Bortolussi, and S.G. Hart. 1987. "In Flight Evaluation of Pilot Workload Measures for Rotorcraft Research." Proceedings of the Fourth Symposium on Aviation Psychology, 637-643. Columbus: Department of Aviation, Ohio State University.

Stachowski, A.A., S.A. Kaplan, and M.J. Waller. 2009. "The Benefits of Flexible Team Interaction During Crises." Journal of Applied Psychology 94: 1536-1543.

Starch, D., and D.E. Ash. 1917. "The Mental Curve of Work." Psychological Bulletin 24: 391-402.

Stevens, R., J.C. Gorman, P. Amazeen, A. Likens, and T. Galloway. 2013. "The Neurodynamics of Teams." Nonlinear Dynamics, Psychology, and Life Sciences 17: 67-86.

Stillman, T.F., R.F. Baumeister, K.D. Vohs, N.M. Lambert, F.D. Fincham, and L.E. Brewer. 2010. "Personal Philosophy and Personnel Achievement: Belief in Free Will Predicts Better Job Performance." Social Psychological and Personality Science 1: 43-50.

Szalma, J.L. 2008. "Individual Differences in Stress Reaction." In Performance Under Stress, edited by P.A. Hancock and J.L. Szalma, 323-357. Aldershot: Ashgate.

Szalma, J.L. 2009. "Individual Differences in Human-Technology Interaction: Incorporating Variation in Human Characteristics into Human Factors Ergonomics Research and Design." Theoretical Issues in Ergonomics Science 10: 381-398.

Szalma, J.L. 2012. "Individual Differences in Stress, Fatigue, and Performance." In The Handbook of Operator Fatigue, edited by G. Matthews, P.A. Desmond, C. Neubauer, and P.A. Hancock, 75-90. Aldershot: Ashgate.

Szalma, J.L., and G.S. Taylor. 2011. "Individual Differences in Response to Automation: The Five Factor Model of Personality." Journal of Experimental Psychology: Applied 17: 71-96.

Szalma, J.L., and G.W.L. Teo. 2012. "Spatial and Temporal Task Characteristics as Stress: A Test of the Dynamic Adaptability Theory of Stress, Workload, and Performance." Acta Psychologica 139: 471-485.

Szymura, B. 2010. "Individual Differences in Resource Allocation Policy." In Handbook of Individual Differences in Cognition: Attention, Memory, and Executive Control, edited by A. Gruszka, G. Matthews, and B. Szymura, 231-246. New York: Springer.

Taylor, J.A. 1953. "A Personality Scale of Manifest Anxiety." Journal of Abnormal and Social Psychology 48: 285-290.

Theoretical Issues in Ergonomics Science, Vol. 16, No. 1 (2015): pg. 20-52. DOI. This article is @ Taylor \& Francis and permission has been granted for this version to appear in e-Publications@Marquette. Taylor \& Francis does not grant permission for this article to be further copied/distributed or hosted elsewhere without the express permission from Taylor \& Francis. 
NOT THE PUBLISHED VERSION; this is the author's final, peer-reviewed manuscript. The published version may be accessed by following the link in the citation at the bottom of the page.

Temple, J.G., J.S. Warm, W.N. Dember, K.S. Jones, C.M. LaGrange, and G. Matthews. 2000. "The Effects of Signal Salience and Caffeine on Performance, Workload, and Stress in an Abbreviated Vigilance Task." Human Factors 42: 183-194.

Thompson, B. 1995. "Stepwise Regression and Stepwise Discriminant Analysis Need to Apply Here: A Guidelines Editorial." Educational and Psychological Measurement 55: 525-534.

Thompson, H.L. 2010. The Stress Effect: Why Smart Leaders Make Dumb Decisions - and What to Do About It. San Francisco, CA: Jossey-Bass.

Tsang, P.S., and W.W. Johnson. 1989. "Cognitive Demand in Automation." Aviation, Space, and Environmental Medicine 60: 130-135.

Valve Corporation. 2011. Counterstrike: Source. Los Angeles, CA: Valve Corporation. Accessed September 30, 2011. http://source.valvesoftware.com.

Vancouver, J.B. 2005. "The Depth of History and Explanation as a Benefit and Bane for Psychological Control Theories." Journal of Applied Psychology 90: 38-52.

Vancouver, J.B., C.M. Thompson, E.C. Tischner, and D.J. Putka. 2002. "Two Studies Examining the Negative Effect of Self-efficacy on Performance." Journal of Applied Psychology 87: 506-516.

Verhagen, P. 1993. "Absenteeism, Accidents and Risk-Taking: A Review Ten Years Later." Safety Science 16: 359-366.

Vidulich, M.A., and M.R. Bortolussi. 1988. "A Dissociation of Objective and Subjective Workload Measures in Assessing the Impact of Speech Controls in Advanced Helicopters." Proceedings of the Human Factors Society Thirty-Second Annual Meeting, 1471-1475. Santa Monica, CA: Human Factors Society.

Vytal, K., B. Cornwell, N. Arkin, and C. Grillon. 2012. "Describing the Interplay Between Anxiety and Cognition: From Impaired Performance Under Low Cognitive Load to Reduced Anxiety Under High Load." Psychophysiology 49: 842-852.

Warm, J.S., W.N. Dember, and P.A. Hancock. 1996. "Vigilance and Workload in Automated Systems." In Automation and Human Performance: Theory and Applications, edited by R. Parasuraman and M. Mouloua, 183-200. Hillsdale, NJ: Lawrence Erlbaum Associates.

Warm, J.S., and H.J. Jerison. 1984. "The Psychophysics of Vigilance." In Sustained Attention in Human Performance, edited by J.S. Warm, 15-57. New York: Wiley.

Warm, J.S., R. Parasuraman, and G. Matthews. 2008. "Vigilance Requires Hard Mental Work and Is Stressful." Human Factors 50: 433-441.

Wickens, C.D. 2002. "Multiple Resources and Performance Prediction." Theoretical Issues in Ergonomics Science 3: 159-177.

Wickens, C.D. 2008. "Multiple Resources and Mental Workload." Human Factors 50: 455-450.

Wierwille, W.W., and T.F. Eggemeier. 1993. "Recommendations for Mental Workload Measurement in Test and Evaluation Environment." Human Factors 35: 263-281.

Yeh, Y.Y., and C.D. Wickens. 1988. "Association of Performance and Subjective Measures of Workload." Human Factors 30: 111-120.

Young, M.S., and N.A. Stanton. 2006. "Mental Workload: Theory, Measurement, and Application." In International Encyclopedia of Ergonomics and Human Factors, edited by W. Karwowski. 2nd ed. vol.1, 507-509. Boca Raton, FL: CRC Press.

Zeeman, E.C. 1977. Catastrophe Theory: Selected Papers: 1972-1977. Reading, MA: Addison-Wesley. Zeidner, M., and G. Matthews. 2011. Anxiety 101. New York: Springer.

Theoretical Issues in Ergonomics Science, Vol. 16, No. 1 (2015): pg. 20-52. DOI. This article is (C) Taylor \& Francis and permission has been granted for this version to appear in e-Publications@Marquette. Taylor \& Francis does not grant permission for this article to be further copied/distributed or hosted elsewhere without the express permission from Taylor \& Francis. 


\section{Author information}

Stephen J. Guastello is a Professor of Psychology at Marquette University in Milwaukee, Wisconsin, where he specializes in industrial-organizational psychology and human factors. He received his $\mathrm{PhD}$ in industrial-organizational psychology from the Illinois Institute of Technology in Chicago in 1982. He is the author or co-editor of five books on applications of nonlinear dynamics in work psychology, author of numerous articles in the same general area and Editorin-Chief of Nonlinear Dynamics, Psychology and Life Sciences.

Anton Shircel is currently a member of the organizational development team at Kohler, Inc., Sheboygan, Wisconsin. He received his BA from Marquette University majoring in Psychology in 2013.

Matthew Malon is currently studying art and design at University of Wisconsin, Milwaukee. He received his BA from Marquette University majoring in Psychology and Philosophy in 2013. He is a former member of the security team at the Milwaukee Public Museum.

Paul Timm is a researcher at the Mayo Clinic in Rochester MN. He received his BA degree from Marquette University majoring in Psychology and Criminology in 2013. 